\title{
Water mass distribution in Fram Strait and over the Yermak Plateau in summer 1997
}

\author{
B. Rudels ${ }^{1}$, R. Meyer ${ }^{2}$, E. Fahrbach ${ }^{2}$, V. V. Ivanov $^{3}$, S. Østerhus ${ }^{4}$, D. Quadfasel ${ }^{5}$ \\ U. Schauer ${ }^{2}$, V. Tverberg ${ }^{6}$, R. A. Woodgate ${ }^{7}$ \\ ${ }^{1}$ Finnish Institute of Marine Research, Lyypekinkuja 3A, P.O. PL33, FIN-00931 Helsinki, Finland \\ e-mail: rudels@fimr.fi \\ ${ }^{2}$ Alfred-Wegener-Institut für Polar und Meeresforschung, Columbus straße, Postfach 120161, D-27515 Bremerhaven, Germany \\ 3 Arctic and Antarctic Research Institute, Ocean/Atmosphere Department, 38, Bering Street, 199397 St. Petersburg, Russia \\ ${ }^{4}$ Geophysical Institute, University of Bergen, Allégaten 70, N-5007 Bergen, Norway \\ ${ }^{5}$ Niels Bohr Institute for Astronomy, Physics and Geophysics, University of Copenhagen, Juliane Maries Vej 30 \\ DK-2100 Copenhagen Ø, Denmark \\ ${ }^{6}$ University Courses of Svalbard, Geophysics Marine Research, Postboks 156/157, N-9170 Longyearbyen, Norway \\ ${ }^{7}$ Applied Physics Laboratory, University of Washington, 1013 NE 40th Street, Seattle, Washington 98105-6698, USA
}

Received: 26 May 1999 / Revised: 23 February 2000 / Accepted: 2 March 2000

\begin{abstract}
The water mass distribution in northern Fram Strait and over the Yermak Plateau in summer 1997 is described using CTD data from two cruises in the area. The West Spitsbergen Current was found to split, one part recirculated towards the west, while the other part, on entering the Arctic Ocean separated into two branches. The main inflow of Atlantic Water followed the Svalbard continental slope eastward, while a second, narrower, branch stayed west and north of the Yermak Plateau. The water column above the southeastern flank of the Yermak Plateau was distinctly colder and less saline than the two inflow branches. Immediately west of the outer inflow branch comparatively high temperatures in the Atlantic Layer suggested that a part of the extraordinarily warm Atlantic Water, observed in the boundary current in the Eurasian Basin in the early 1990s, was now returning, within the Eurasian Basin, toward Fram Strait. The upper layer west of the Yermak Plateau was cold, deep and comparably saline, similar to what has recently been observed in the interior Eurasian Basin. Closer to the Greenland continental slope the salinity of the upper layer became much lower, and the temperature maximum of the Atlantic Layer was occasionally below $0.5^{\circ} \mathrm{C}$, indicating water masses mainly derived from the Canadian Basin. This implies that the warm pulse of Atlantic Water had not yet made a complete circuit around the Arctic Ocean. The Atlantic Water of the West Spitsbergen Current recirculating within the strait did not extend as far towards Greenland as in the 1980s, leaving a broader passage for waters from the Atlantic and intermediate layers, exiting the Arctic Ocean. A possible interpretation is that the circulation pattern alternates between a strong recirculation of the West Spitsbergen Current in the strait, and a larger exchange of Atlantic Water between the Nordic Seas and the inner parts of the Arctic Ocean.
\end{abstract}

Correspondence to: $\mathrm{B}$. Rudels
Key words: Oceanography: general (Arctic and Antarctic oceanography; water masses) Oceanography: physical (general circulation)

\section{Introduction}

Fram Strait has long been considered the most important communication link between the Arctic Ocean and the Nordic Seas. At the turn of the century, it was known that an outflow of cold polar water and sea ice took place through the strait, and that a warm subsurface layer, originating from an inflow of warm Atlantic Water (AW) through Fram Strait, was present in the interior of the Arctic Ocean (Nansen, 1902). It was, however, believed that the export of Polar Surface Water (PSW) dominated the exchanges, and that the main inflow from the Nordic Seas to the Arctic Ocean passed over the Barents Sea (Helland-Hansen and Nansen, 1909). The Barents Sea inflow, after interacting with run-off from the Siberian rivers, would then supply most of the PSW, and, because of freezing, brine rejection, and the formation of dense water over the shallow shelves, perhaps partly ventilate the deeper layers of the Arctic Ocean (Nansen, 1906). Nansen, however, later came to believe that the deep water in the Arctic Ocean derived from the Greenland Sea and entered through Fram Strait (Nansen, 1915). Almost all of these conjectures have been found to be valid. Even Nansen's initial suggestion $(1902,1906)$ that the Arctic Ocean deep waters were formed by slope convection, bringing brine-enriched shelf water into the deep Arctic Ocean basins, is now considered a more important process for the ventilation of the deep Arctic Ocean than an inflow of deep water from the Nordic Seas. (Aagaard et al., 1985; Jones et al., 1995). 
The severe climate and the presence of sea ice make the observation conditions in Fram Strait harsh, and the early transport estimates were derived, either from geostrophic velocities calculated for the ice-free part of the strait, dominated by the West Spitsbergen Current, and/or from mass and salt conservation arguments (Timofeyev, 1961, 1963; Mosby, 1962; Vowinckel and Orvig, 1970). In the 1970s the first year-long time series from current meters moored in the West Spitsbergen Current became available (Aagaard et al., 1973), and the transport estimates for the West Spitsbergen Current rose from 3-4 Sv to $7 \mathrm{~Sv}\left(1 \mathrm{~Sv}=10^{6} \mathrm{~m}^{3} \mathrm{~s}^{-1}\right)$. Fram Strait became regarded as the most important passage, not just for exiting polar waters, but also for the inflow of Atlantic Water from the Nordic Seas. Aagaard and Greisman (1975) worked out a mass budget for the Arctic Ocean, where the inflow and outflow through Fram Strait were balanced and, in addition to an outflow of $1.8 \mathrm{~Sv}$ of PSW, 5.3 Sv of cooled Modified Atlantic Water (MAW) were exported from the Arctic.

These results, and the importance of the meridional oceanic heat and freshwater transports for the climate of the Arctic, led to intensified measuring activity in Fram Strait. HMS Ymer made complete crossings in 1980 (Rudels, 1987). In 1983 and 1984 the Marginal Ice Zone Experiment (MIZEX) studied atmosphere-ice-ocean interactions and mixing processes associated with the meeting of the northward-flowing West Spitsbergen Current and polar water and ice, exiting the Arctic Ocean in the East Greenland Current. Several complete crossings of the strait were made during MIZEX and in the years after (Quadfasel et al., 1987; Bourke et al., 1988), and the current meter observations were extended westward to the East Greenland Current (Foldvik et al., 1988). These studies showed that the recirculation of AW in Fram Strait was considerable and that the inflow of AW to the Arctic Ocean was much smaller (0.61.5 Sv, Aagaard and Carmack, 1989) than previously estimated. The measured outflow of $3 \mathrm{~Sv}$ in the East Greenland Current above $700 \mathrm{~m}$ (Foldvik et al., 1988) then suggested a stronger inflow to the Arctic Ocean over the Barents Sea than through Fram Strait, in agreement with the earlier view (Helland-Hansen and Nansen, 1909).

In contrast to Fram Strait proper, the area north of the strait has been less systematically studied and mainly by extensive, but shorter, field campaigns: e.g., the airborne Eurasian Basin Experiment (EUBEX) in the western Eurasian Basin (Perkin and Lewis, 1984), partly MIZEX, and the Co-ordinated Eastern Arctic Experiment (CEAREX) north of Svalbard and over the Yermak Plateau (Muench et al., 1992; Padman et al., 1992). The general hydrographic conditions in the area and their relations to the Arctic Ocean and to the Greenland Sea can be found in the atlases compiled by Gorshkov (1980) and Koltermann and Lüthje (1987).

The volume of Atlantic Water entering the Arctic Ocean through Fram Strait may be smaller than that passing over the Barents Sea, but Fram Strait is the most important passage for oceanic sensible heat to the central Arctic. This northward transport melts south- ward-drifting sea ice and maintains the open water north of Svalbard, known as the Whalers' Bay (Aagaard et al., 1987; Untersteiner, 1988). Fram Strait is the only deep connection to the Arctic Ocean, and although the outflow of PSW through the Canadian Arctic Archipelago is about as large as that leaving through Fram Strait ( 1 Sv) (Rudels, 1986; Steele et al., 1996), all denser water masses must exit through Fram Strait. Furthermore, $>90 \%$ of the sea ice exported from the Arctic Ocean passes through Fram Strait (Vowinckel and Orvig, 1970).

Recent studies have shown that the circulation in the Arctic Ocean comprises several loops and the waters passing along the separate loops, acquire different characteristics (Rudels et al., 1994; McLaughlin et al., 1996). Intensified field work in the interior of the Arctic Ocean, from ice breakers as well as from submarines, has also revealed substantial variations in the water mass characteristics compared to the climatological (and previously assumed quasi-stationary) water mass properties of the interior Arctic Ocean (Quadfasel et al., 1991; Carmack et al., 1995; Morison et al., 1998; Steele and Boyd, 1998). These variations imply changes in the water mass transformations in the Nordic Seas, and in the Arctic Ocean, that eventually could affect the global thermohaline circulation through the overflow of dense water across the Greenland-Scotland Ridge. The international Arctic Ocean System Study (ACSYS) coordinated by the World Climate Research Programme (WCRP), and the European Commission programme on the Variability of Exchanges in the Northern Seas Programme (VEINS), among others, are investigating this variability. VEINS involves a simultaneous study of the exchanges through the four main passages to the Nordic Seas: the Faeroe-Shetland Channel: the Barents Sea; Fram Strait; and Denmark Strait.

\section{Observations}

Hydrographic observations were made on the ARKXIII-2 cruise of RV Polarstern in July 1997 and included two crossings (sections II and III) of the northern Fram Strait and the Yermak Plateau, and a short meridional section (V) north of Spitsbergen (Fig. 1a) (Stein and Fahl, 1997). One month later, during a cruise with RV Lance in Fram Strait proper, a zonal hydrographic section, along $78^{\circ} 50^{\prime} \mathrm{N}$ in the eastern and along $79^{\circ} \mathrm{N}$ in the western part of the strait, was added (section I, Fig. 1a). A meridional section (IV) was also taken, extending northward from the center of the Boreas Basin along the axis of the strait and then turning east

Fig. 1. a Map showing the bathymetry of Fram Strait and the positions of the stations and sections occupied by RV Polarstern and by RV Lance in summer 1997. The gray parts indicate stations used on more than one section. b Map of the Eurasian Basin showing the positions of the 1991 Oden-91 stations and 1995 (ARKXI) and 1996 ( $A R K X I I)$ Polarstern stations discussed in the text 

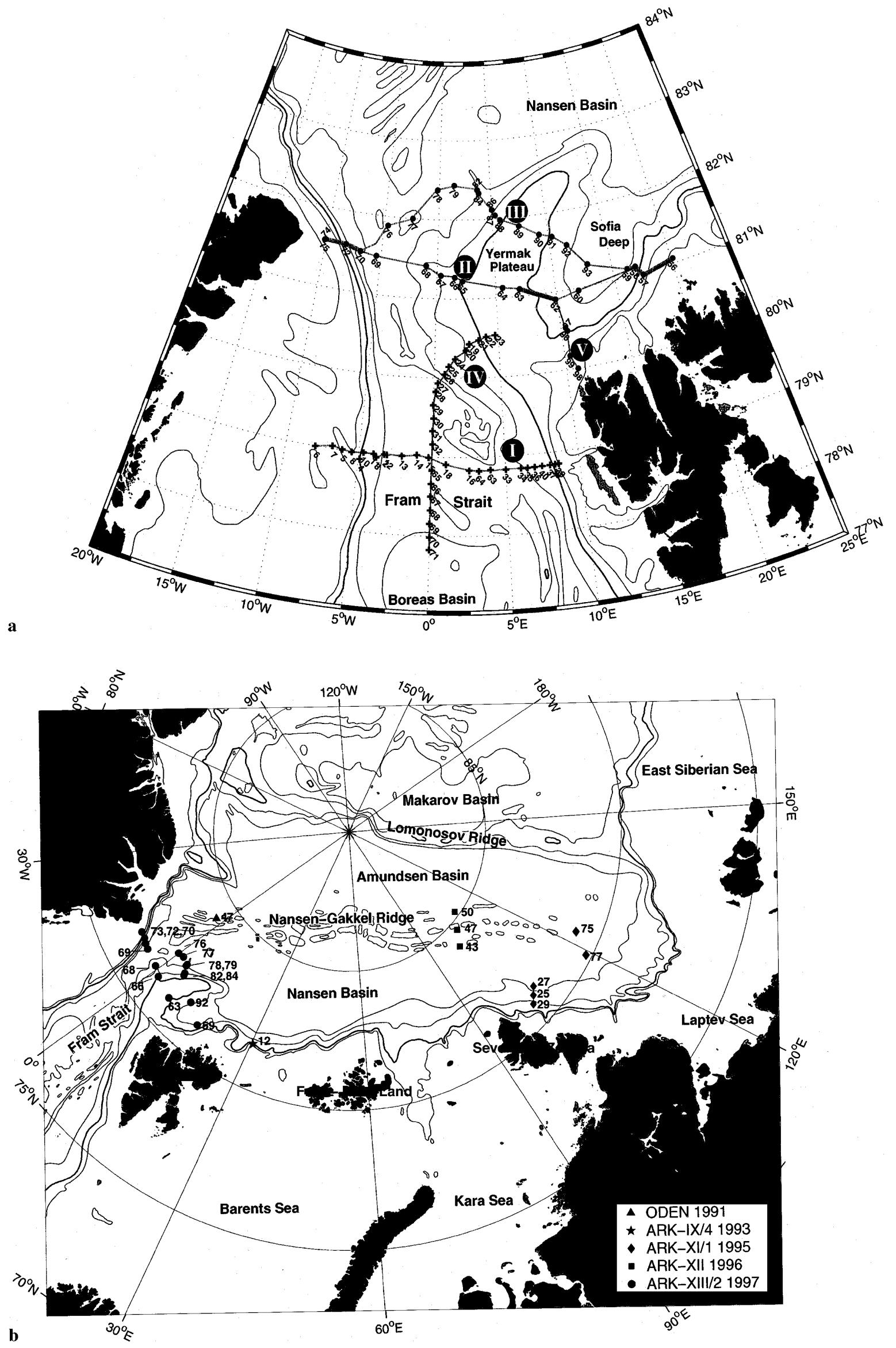
onto the southern part of the Yermak Plateau (Fig. 1a) (Schauer and Østerhus, 1997).

On Polarstern a SeaBird SBE 911 CTD system was used. The original conductivity cell was somewhat noisy, and finally broke (at station 67/97). It was replaced, and the new sensor was more stable and performed better. To calibrate the CTD conductivity salinity samples were taken and analyzed on board on a Guildline 8400 Autosal. The accuracy of the salinity is estimated to 0.004 . On Lance the observations were made with a NBIS MkIII CTD. Salinity samples were taken and analysed on board, also here using a Guildline 8400 Autosal. The accuracy of the salinity is estimated to 0.003 .

The present work aims at a qualitative description of the hydrographic conditions as observed in summer 1997, concentrating on the circulation of different water masses in the strait and above the Yermak Plateau. We mainly do this using the core method introduced by Wüst (1936), but also use observed interleaving structures as tracers to identify sources and pathways. The waters from the Nordic Seas and from the Arctic Ocean are examined at different levels. Section 3 concentrates on the upper layers, i.e., Atlantic inflow (Sect. 3.1), the outflowing Polar Surface Water (Sect. 3.2), and the Modified Atlantic Water (MAW) leaving the Arctic Ocean (Sect. 3.3). The layering structures are discussed in Sect. 4, and the intermediate and deep waters are described in Sect. 5 and Sect. 6 respectively. The implied circulation in the different layers is summarized schematically on horizontal maps (see later). In Sect. 7 the water mass characteristics observed in the northern Fram Strait are compared with recently reported property changes in the Arctic Ocean, and the findings are summarized in the conclusion (Sect. 8). The positions of the stations from earlier expeditions, Oden-1991, and the ARK-IX (1993), ARK-XI (1995) and ARK-XII (1996) expeditions with RV Polarstern, and used here, are shown in Fig. 1b. The adopted water mass classification (Fig. 2) is a simplified version of that introduced by Friedrich et al. (1995) and shown in Rudels et al. (1999).

\section{The upper layers}

\subsection{The inflow of Atlantic Water $A W$}

The subsurface, warm $\left(\Theta>0{ }^{\circ} \mathrm{C}\right)$, water mass in the Arctic Ocean, here called the Atlantic Layer, is supplied by AW that enters through Fram Strait in the West Spitsbergen Current (Nansen, 1902). Sections I, II and III (Fig. 3a-c) across the strait show that the West Spitsbergen Current consisted of several cores. The warmest, and most saline, $\left(\Theta>3{ }^{\circ} \mathrm{C}, \mathrm{S}>35\right)$ water on section I was found at the Svalbard continental slope, but the AW extended far to the west and occupied most of the cross section down to $500 \mathrm{~m}$ (Fig. 3a). On sections II and III, further to the north, the AW had two distinct cores, one over the slope and extending into the Sofia Deep $\left(\Theta>2{ }^{\circ} \mathrm{C}, \mathrm{S}>34.94\right)$, the other

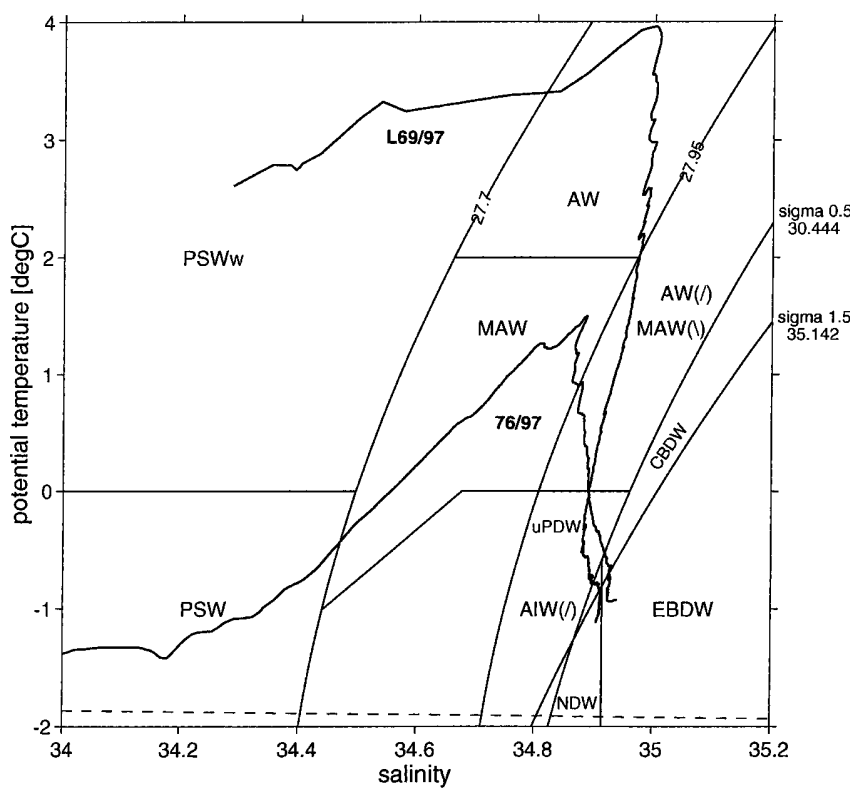

Fig. 2. Restrictions to be fulfilled by the different water masses. The definitions are based on Friedrich et al. (1995) and Rudels et al. (1999). $P S W$ (Polar Surface Water), $\sigma_{0}<27.70, \Theta<0{ }^{\circ} \mathrm{C} ; \mathrm{PSW}$ (Polar Surface Water warm, essentially ice melt water above the Atlantic Water), $\sigma_{0}<27.70,0{ }^{\circ} \mathrm{C}<\Theta ; A W$ (Atlantic Water from the south), $27.70<\sigma_{0}<27.97,2{ }^{\circ} \mathrm{C}<\Theta$, or $27.97<\sigma_{0}$, and $\sigma_{0.5}<30.444$, $0{ }^{\circ} \mathrm{C}<\Theta$, and the water column unstable in the finger sense; $M A W$ (Modified Atlantic Water from the Arctic Ocean) 27.70 $<\sigma_{0}<27.97, \Theta<0{ }^{\circ} \mathrm{C}, \mathrm{S}<34.676+0.232 \Theta$, or $27.97<\sigma_{0}$, and $\sigma_{0.5}<30.444,0{ }^{\circ} \mathrm{C}<\Theta$, and the water column stable in both component; $u P D W$ (upper Polar Deep Water from the Arctic Ocean) $29.97<\sigma_{0}, \sigma_{0.5}<30.444, \Theta<0{ }^{\circ} \mathrm{C}$ and the water column stable in both component; $A I W$ (Arctic Intermediate Water from the Greenland Sea), $27.97<\sigma_{0}, \sigma_{0.5}<30.444, \Theta<0{ }^{\circ} \mathrm{C}$ and the water column unstable in one component; $C B D W$ (Canadian Basin Deep Water), $30.444<\sigma_{0.5}, \sigma_{1.5}<35.142,34.915<\mathrm{S} ; E B D W$ (Eurasian Basin Deep Water), $35.142<\sigma_{15}, 34.915<\mathrm{S} ; N S D$ (Nordic Sea deep waters from the Greenland and Norwegian Seas), $30.444<\sigma_{0.5}$, $\mathrm{S}<34.915$. Note that the separation in salinity between the Arctic Ocean and the Nordic Seas deep waters is at 34.915 instead of 34.92 used in Friedrich et al. (1995). The broken line indicates the freezing point of seawater. The characteristics of the empty box in the $\Theta-S$ diagram between the PSW and the intermediate waters are not present in Fram Strait, but may be encountered in the top layer of the central Iceland and Greenland Seas. The figure also shows the warmer station L69/97 from the south and the cold station 76/97 from the north

$\left(\Theta>1.5^{\circ} \mathrm{C}, \mathrm{S}>34.93\right)$, located above the western and northern flank of the Yermak Plateau (Fig. 3b, c). On the short north-south section $\mathrm{V}$ on the Yermak Plateau the warmest and most saline AW $\left(\Theta>4{ }^{\circ} \mathrm{C}\right.$, $\mathrm{S}>35$ ) was observed to the south, indicating that the major inflow took place close to Svalbard (Fig. 4). The AW in the Sofia Deep was as warm and saline as that at the northern Svalbard slope, and warmer and more saline than the AW core west of the Yermak Plateau (Fig. 3b, c). The AW in the Sofia Deep would then mainly be supplied by the eastern inflow branch, as proposed by Aagaard et al. (1987) and Bourke et al. (1988), rather than from the outer branch circulating around the Yermak Plateau, suggested by Perkin and Lewis (1984). A further possibility exists. Subsurface 

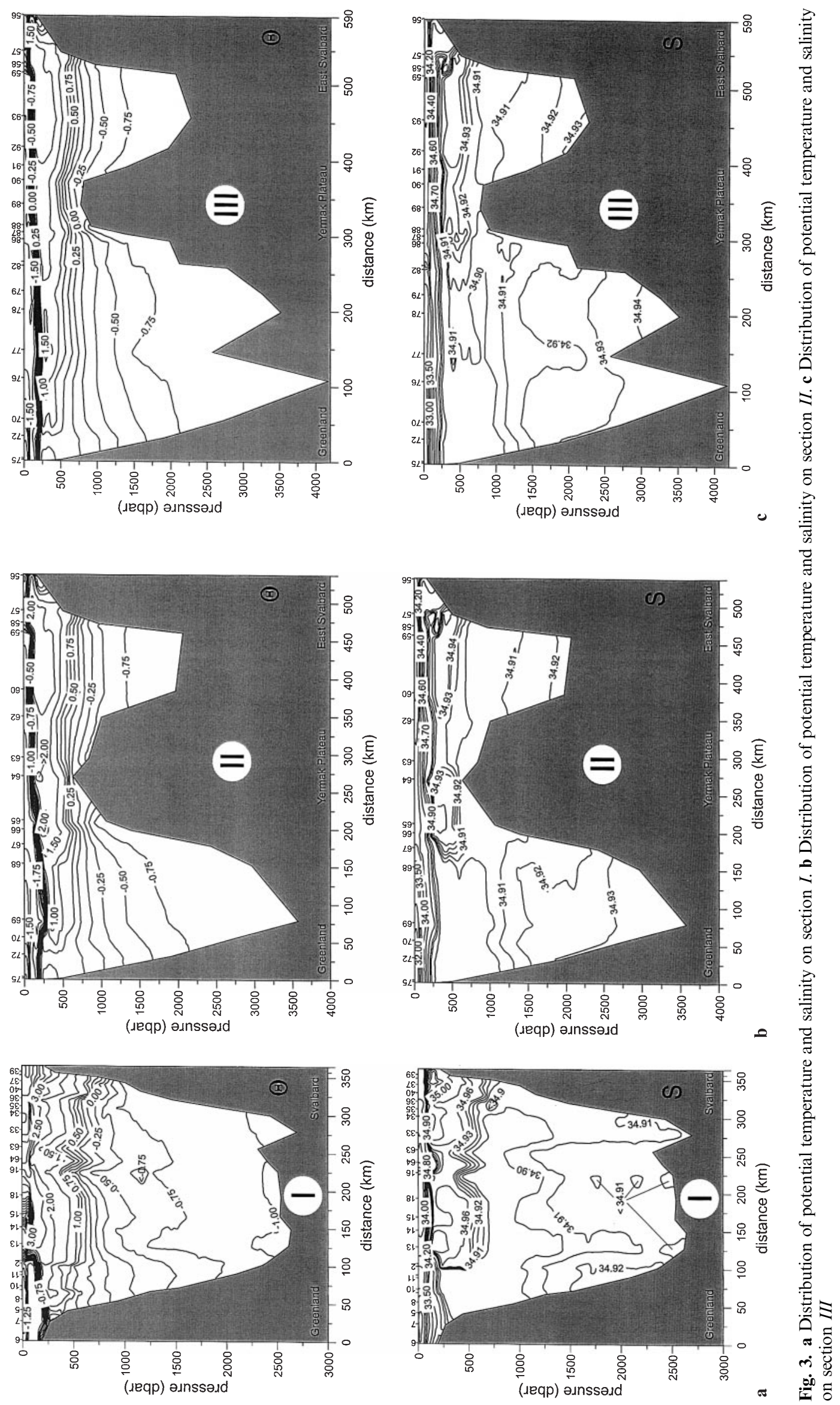

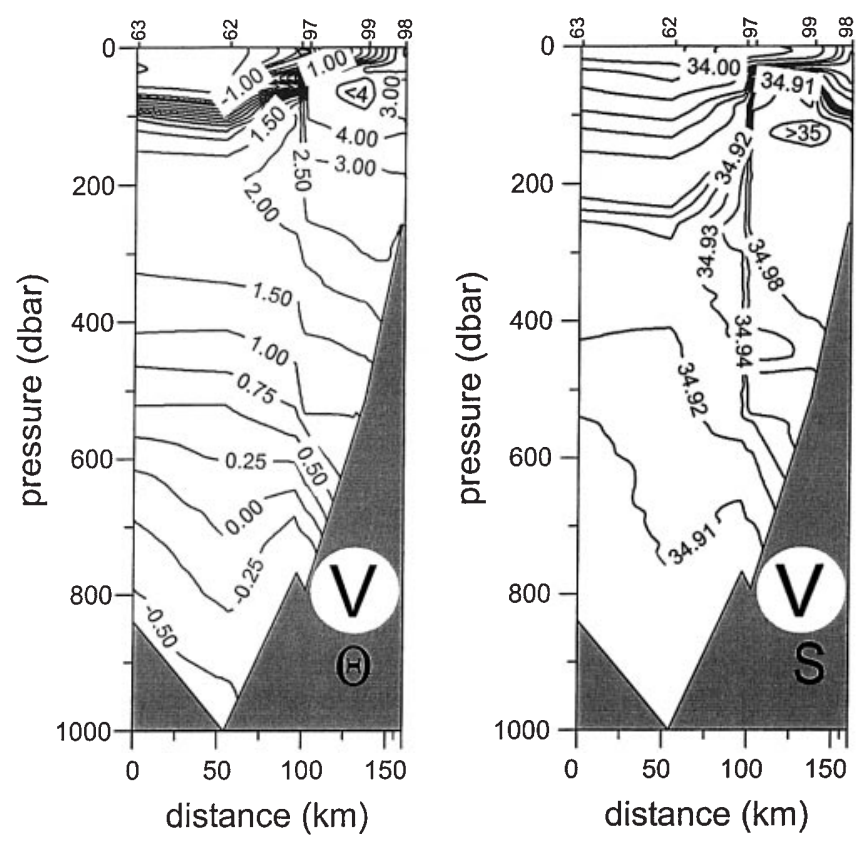

Fig. 4. Distribution of potential temperature and salinity on the north-south section $V$ at the southern part of the Yermak Plateau

floats, deployed in the AW core of the West Spitsbergen Current, were found to cross the southern part of the Yermak Plateau into the Sofia Deep, above a previously undetected gap in the plateau (Gascard et al., 1995). No such inflow was, however, evident on the northern part of section V (Fig. 4).

The AW core west of the Yermak Plateau continued along the northwestern flank of the plateau and entered the Arctic Ocean, as proposed by Perkin and Lewis (1984). No sign of a westward recirculation of AW was seen on section II (Fig. 3b, and Fig. 5). However, the westward extension of the AW layer on section I indicated that a part of the West Spitsbergen Current recirculates between sections I and II. It then passes through the northern part of section IV (Fig. 6). Temperatures in the western part of section I were occasionally higher than on the entire section IV (compare Figs. 3a and 6), implying either that the recirculation branches were exceedingly narrow, and missed by the station spacing on section IV, or that the westward circulation became fragmented into individual eddies, drifting west and south across the sections (Gascard et al., 1995).

Above the southeastern part of the Yermak Plateau the water column was denser, and the AW core colder and fresher than in the two inflow branches (Station 63/ 97 in Fig. 7). Two processes could influence the water column at the Yermak Plateau. Firstly, the cyclonic surface circulation over the plateau (Muench et al., 1992) causes a doming of the isopycnals, forcing deeper, colder and less saline water upwards. Secondly, the intensification of the tidal motions over the plateau (Hunkins, 1986) provides turbulent kinetic energy for enhancing vertical mixing, leading to an increased vertical heat flux to the pycnocline, lowering the heat content of the AW layer (Padman and Dillon, 1991).

\subsection{The Polar Surface Water PSW}

The low salinity, upper water north of Svalbard is formed as sea ice melts on top of the inflowing AW (Untersteiner, 1988). This PSW follows the boundary current eastward. It is homogenized by freezing and haline convection in winter and eventually becomes an

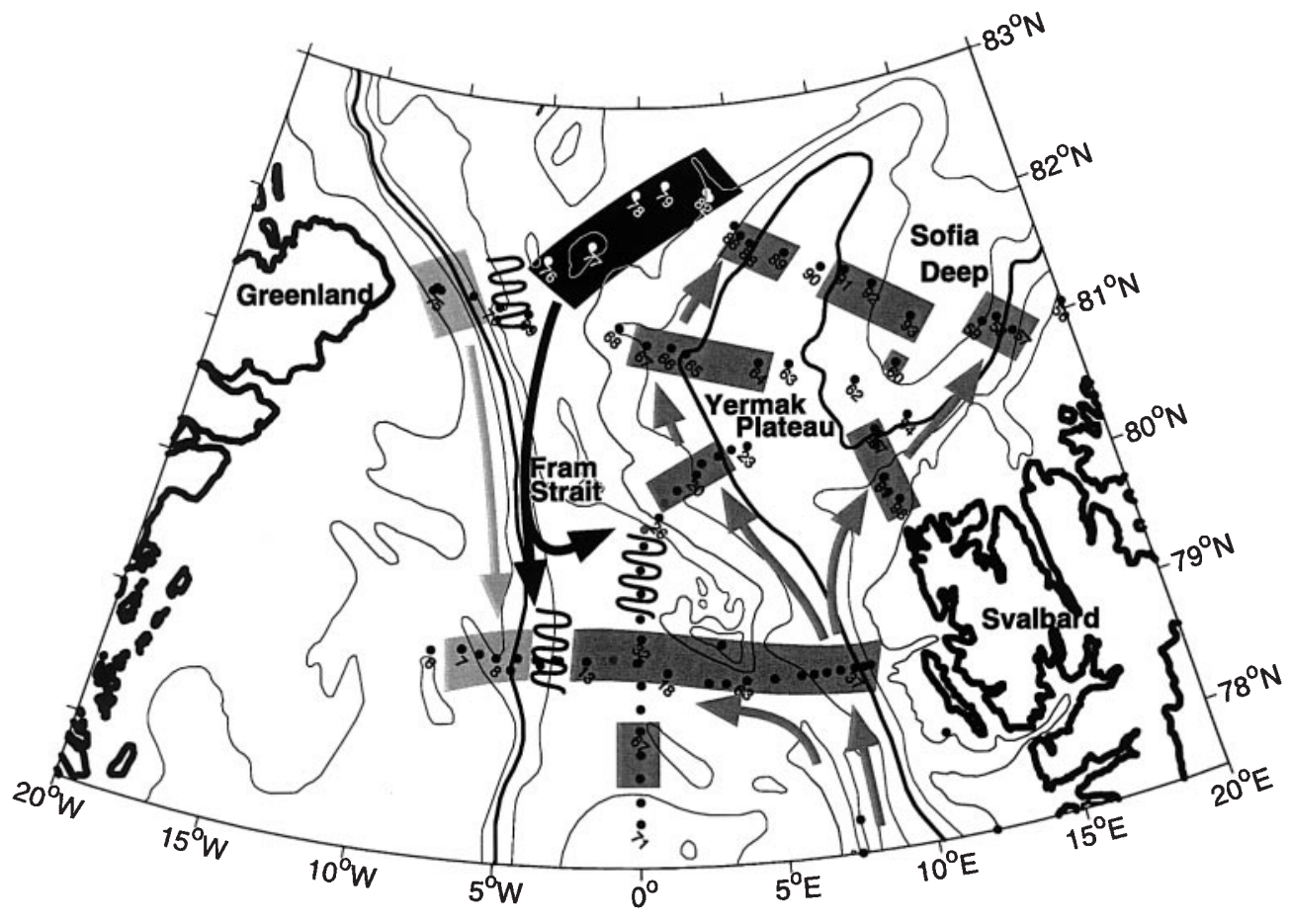

Fig. 5. Horizontal distribution of Atlantic Water. Dark gray shading shows the presence of AW, light gray denotes MAW from the Canadian Basin and black MAW from the Eurasian Basin. Arrows denote proposed pathways of the different waters. Wriggly lines indicate interleaving between converging water masses 

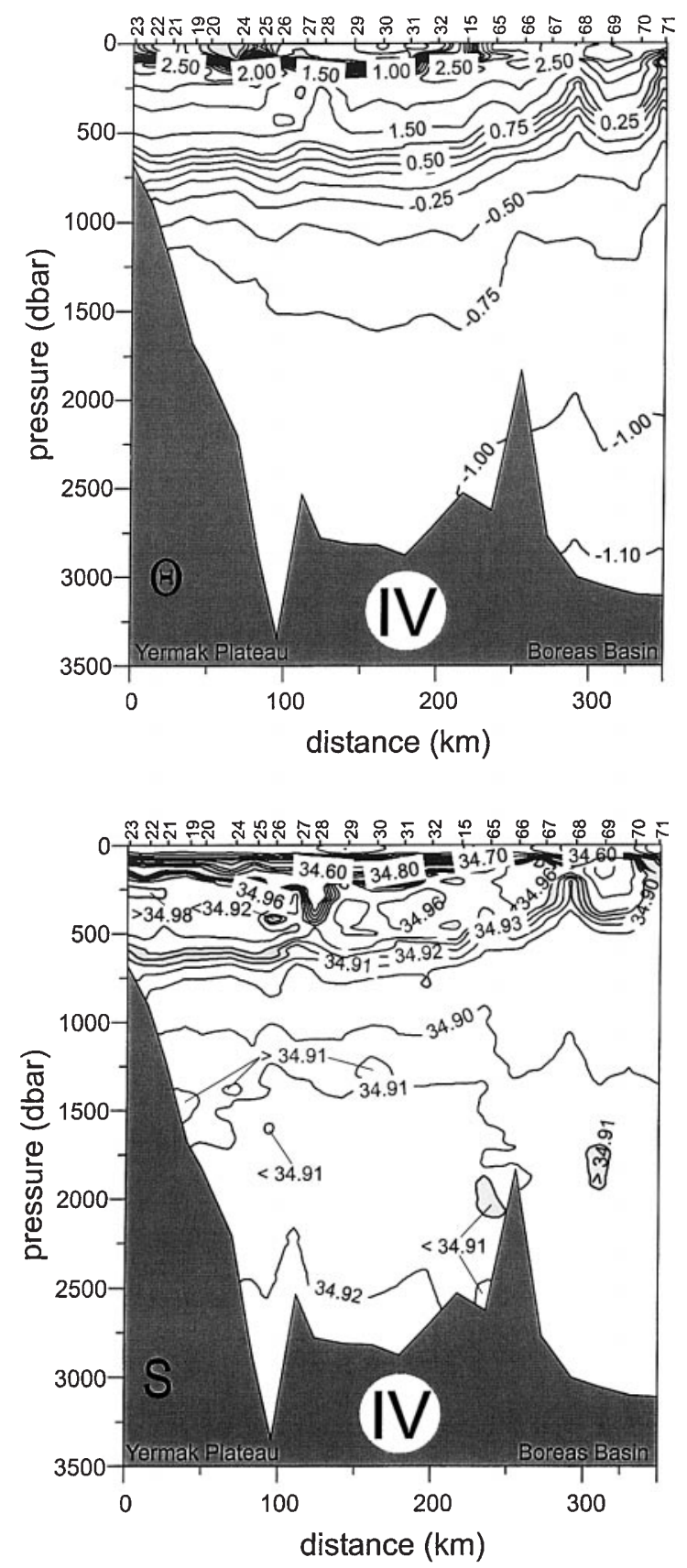

Fig. 6. Distribution of potential temperature and salinity on the north-south section $I V$ along the axis of Fram Strait

important constituent of the Arctic Ocean halocline (Carmack, 1990; Steele et al., 1995; Rudels et al., 1996). West of the Yermak Plateau the PSW layer was deeper. Below the less saline and warmer surface water, created by seasonal summer heating and ice melt, it was almost homogenous and extended down to $150 \mathrm{~m}$ (Station 82/ 97 in Fig. 8a). The temperature profile exhibited a temperature minimum, indicating the depth of convection and homogenization during the previous winter. The salinity was high and constant, close to 34.3 down to the thermocline.

A salinity of 34.2-34.3 in the Arctic Ocean has often (Coachman and Aagaard, 1974; Aagaard et al., 1981;
Jones and Anderson, 1986) been related to the "lower" halocline, below the Polar Mixed Layer (PML), which separates the Atlantic Layer from the surface processes (Station 47/91 in Fig. 8a). Jones and Anderson (1986) found the temperature of the lower halocline to be around $-1{ }^{\circ} \mathrm{C}$, well above freezing, supporting the view that heat lost by the Atlantic Layer is trapped in the halocline. The lowest temperatures in this salinity range have been observed north of the Barents and Kara Seas (e.g., Treshnikov et al., 1976), and it has been interpreted as an outflow of cold, fairly saline shelf water from these seas (Coachman and Aagaard, 1974).

By contrast, Rudels et al. (1996) assumed that no surface water of salinity lower than the PSW is exported from the Barents Sea and Kara Sea shelves, and that the halocline and the Polar Mixed Layer (PML) do not exist as separate, and distinct water masses north of these seas. Instead the halocline and the thermocline coincide, forming the pycnocline below a deep PSW layer. The PSW layer is advected eastward with the boundary current and homogenized down to the pycnocline by haline convection in winter. As it reaches the Laptev Sea, it encounters the low salinity shelf water input, and a separation into an upper PML, and an isolated, and insulating, halocline takes place. After this the temperature of the halocline increases, due to heat input from the Atlantic Layer below, in agreement with its higher temperature in e.g., the Canadian Basin (Jones and Anderson, 1986).

Surface salinities close to 34.3 have recently been observed in the eastern Eurasian Basin (Station 50/96 in Fig. 8a). Such high salinities have also been reported from extensive areas in the Amundsen Basin by Steele and Boyd (1998), who describe this as a retreat of the cold halocline water. In the explanation proposed by Rudels et al. (1996) a high surface salinity, such as that on station 50/96, should be interpreted as an absence of the PML in parts of the interior Eurasian Basin. This implies that in recent years the low salinity surface outflow from the Laptev Sea has not entered the Eurasian Basin, but the Canadian Basin, as proposed by Proshutinsky and Johnson (1997) and Steele and Boyd (1998). The similarity between stations 50/96 and 82/97 (Fig. 8a) then suggests that the PSW presently returning from the Eurasian Basin toward Fram Strait mostly comprises the initial, winter homogenized "ice melt" layer from north of Svalbard. The water of the halocline has not "retreated". If anything, it has expanded towards the sea surface.

The salinity and depth of the temperature minimum decreased westward, and it was found at $60-70 \mathrm{~m}$ at the Greenland slope and shelf (Fig. 8a, station 72/97). Two temperature minima were observed close to Greenland, suggesting a different source for the upper, less saline water than for the underlying part (Station 72/97 in Fig. 8a). Streams of PSW from different parts of the Arctic Ocean converge north of Fram Strait, and less dense water spreads above a denser stream. The low salinity upper layer most likely originates in the Canadian Basin and overruns the denser PSW of the Eurasian Basin. The temperature of the lower minimum was above freezing, indicating that the deeper water mass 

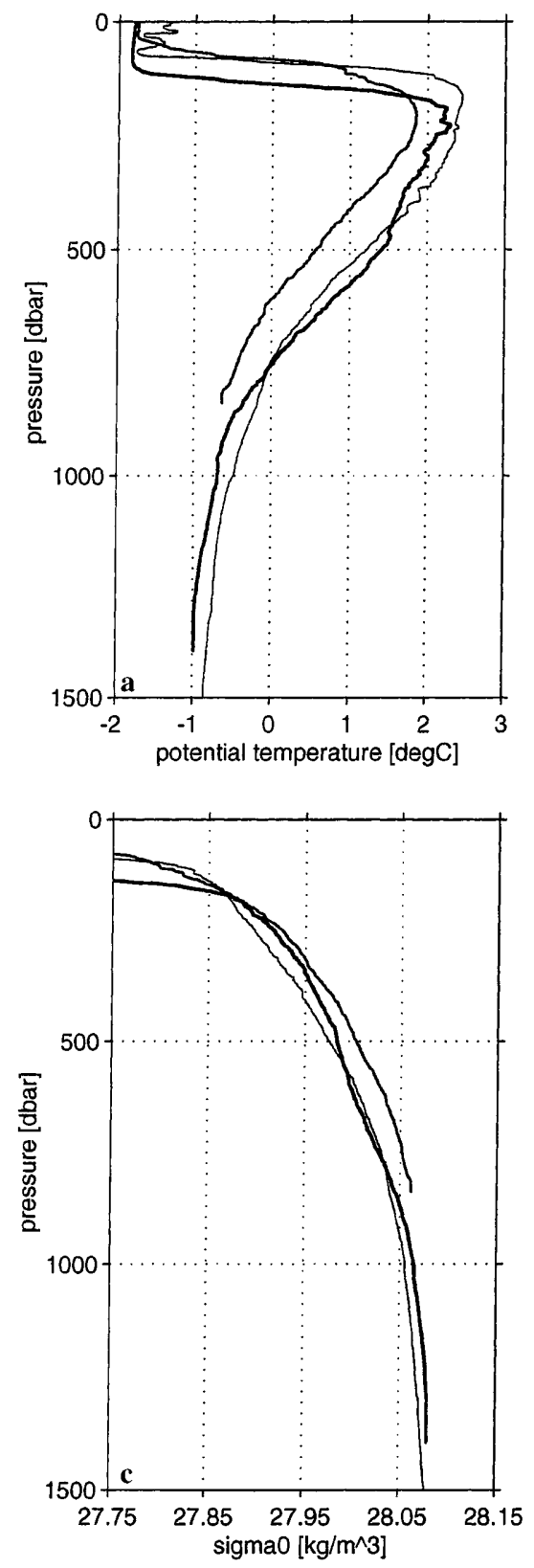
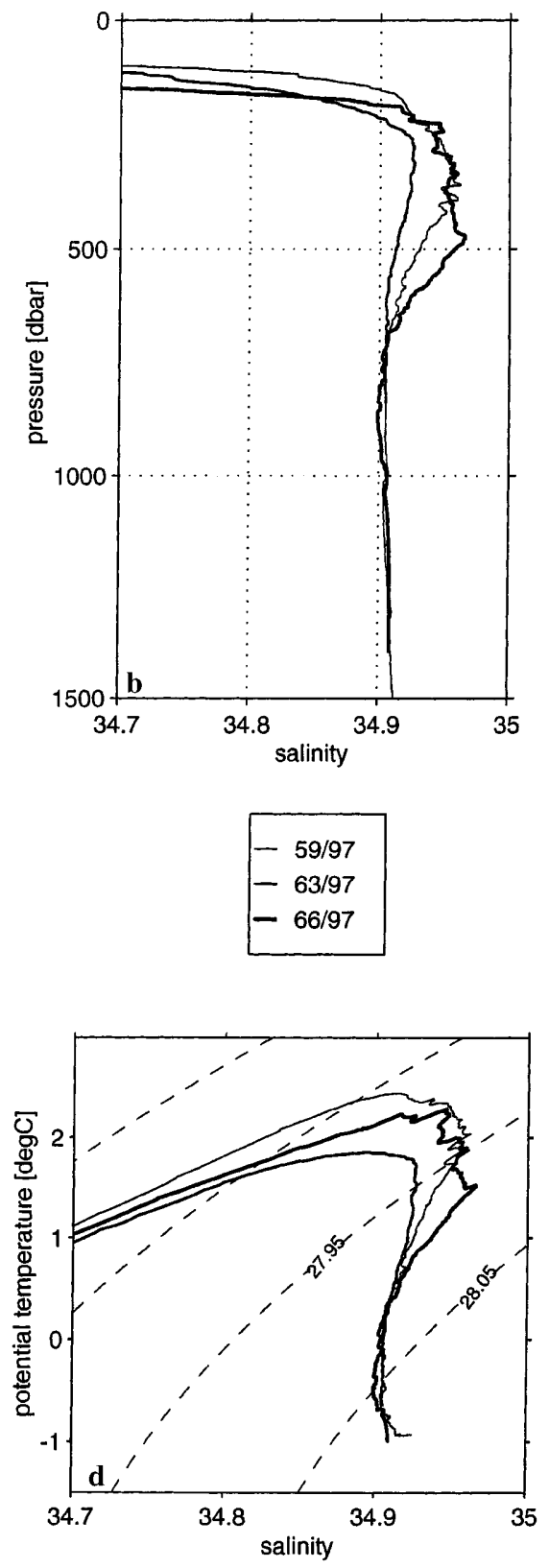

Fig. 7a-d. Profiles of potential temperature, salinity and potential density, and $\Theta-S$ diagram showing the difference between the Yermak Plateau water column $(63 / 97)$ and that of the two inflow branches $(59 / 97$ and 66/97) had been isolated from the winter convection and that its temperature had increased by mixing with warmer water from below. A more recent convergence was seen at station $69 / 97$ (Fig. 8b). The temperature was close to freezing as deep as $240 \mathrm{~m}$, and the lower part of the salinity profile was similar to that found between 60 and $140 \mathrm{~m}$ at the neighboring station $(68 / 97)$ to the east (Fig. 8b). The layer between 50 and $100 \mathrm{~m}$ had the same salinity and temperature as the 0-60 m layer of station $68 / 97$, while between 0 and $50 \mathrm{~m}$ the salinity was as low as at the Greenland continental slope (Station 70/97 in Fig. 8 b). Deflecting the upper part of station $70 / 97$ on top of station 68/97 would then result in the salinity and temperature profiles observed at station 69/97.

A temperature minimum with salinity around 34.3 could also be identified on the western part of section I, where it formed the bulk of the $>150 \mathrm{~m}$ deep PSW
(Station L8/97 in Fig. 8b) showing the southward continuation of the Eurasian Basin PSW. On the westernmost part of section I the surface salinity was very low (Figs. $3 \mathrm{a}$ and $8 \mathrm{~b}$ ). This indicates that PSW from the Canadian Basin with a large fraction of Pacific Water (PW) was exiting through Fram Strait. A concentration of PW towards Greenland was already noticed in 1991 (Anderson et al., 1994) and a PW outflow through Fram Strait has also been identified from the nutrient distribution (Jones et al., 1998).

\subsection{Water exiting the Atlantic Layer of the Arctic Ocean MAW}

West of the Yermak Plateau the temperature and salinity of the Atlantic Layer decreased towards the 

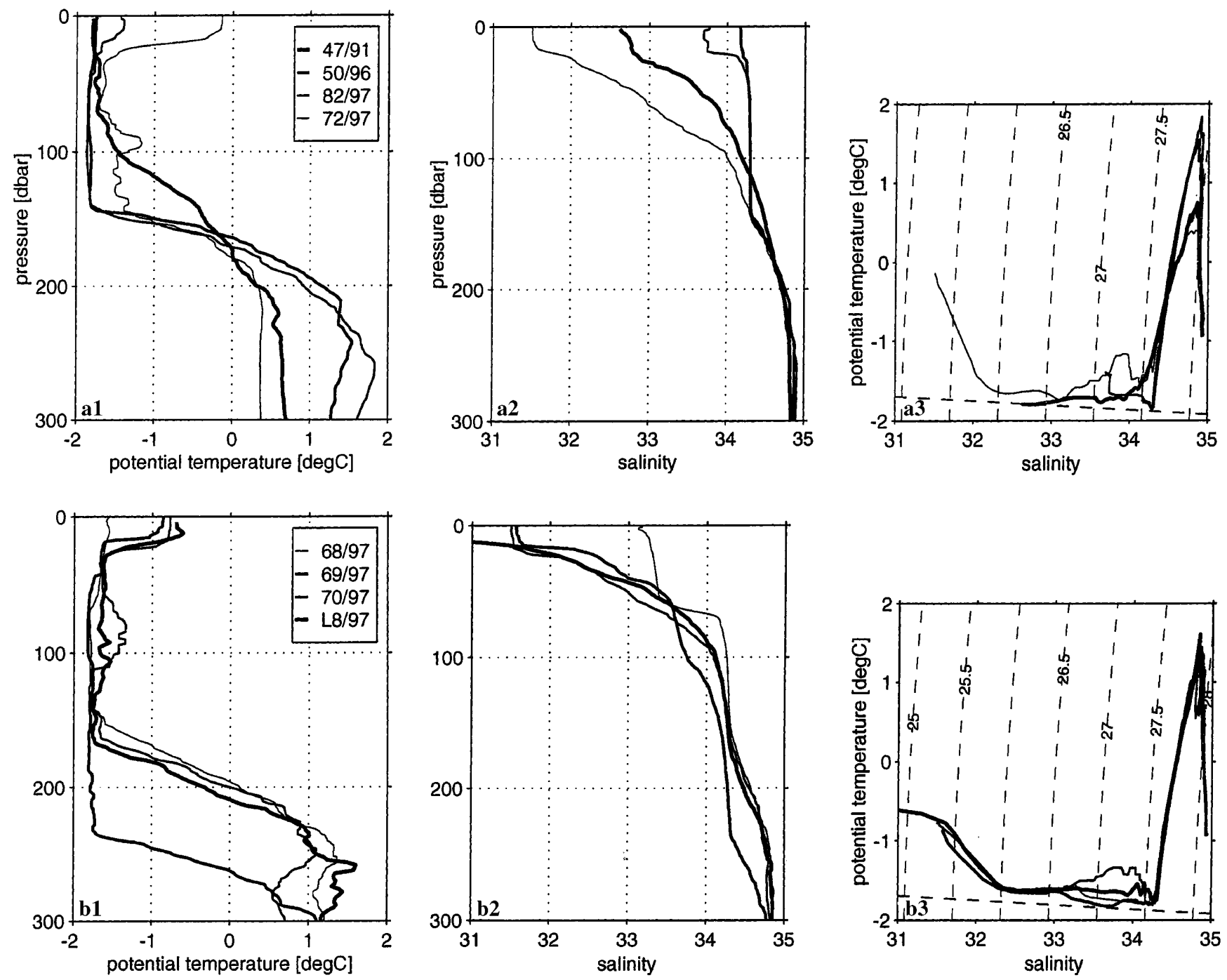

Fig. 8. a Profiles of potential temperature (a1) and salinity (a2) for the upper $300 \mathrm{~m}$, and $\Theta-\mathrm{S}$ curves (a3) showing the winter mixed layers observed north of the Yermak Plateau in 1991 (47/91), in the central Eurasian Basin in 1996 (50/96), north of the Yermak Plateau in 1997 $(82 / 97)$ and at the Greenland slope in northern Fram Strait (72/97); b profiles of potential temperature $(b 1)$ and salinity $(b 2)$ for the upper $300 \mathrm{~m}$, and $\Theta-\mathrm{S}$ curves $(\mathrm{b} 3)$ showing the different depth of the winter mixed layer on section II $(68 / 97,69 / 97$ and 70/97) and in the western part of section I $(L 8 / 97)$ west, and at the Greenland slope the temperature maximum was below $0.5^{\circ} \mathrm{C}$. (Fig. 3b). This indicates the presence of MAW, cooled and freshened along its path through the Arctic Ocean, and now returning toward Fram Strait. The low temperatures close to Greenland imply that MAW here had taken the longer path around the Canadian Basin. This low temperature core of the Canadian Basin MAW could be identified at the continental slope on section I (Figs. 3a, 5). On section III, closer to the Yermak Plateau, the MAW was comparatively warm, suggesting water returning from the Eurasian Basin (Fig. 3c). The MAW on section III was also characterized by strong and very regular inversions and layering structures (Fig. 9a). Individual layers could be identified, and followed, over the main part of section III west of the Yermak Plateau.

Inversions and layers have been observed earlier in Fram Strait and north of the Yermak Plateau (Perkin and Lewis, 1984), but the increased observational coverage has shown that layers are present extensively over the entire Arctic Ocean. The most conspicuous structures have been located in the Atlantic Layer, but layers have also been found at deeper levels (Quadfasel et al., 1993; Rudels et al., 1994; Carmack et al., 1995, 1997; Rudels et al., 1999).

Layering structures, or interleaving, are believed to form at frontal zones by instabilities, either caused by double-diffusive processes (Stern, 1967; Ruddick and Turner, 1979; Toole and Georgi, 1981; McDougall, 1985a, b; Ruddick, 1992), or by the baroclinicity of the flow field (May and Kelley, 1997). Here we shall not discuss the physics behind the process(es) ultimately creating the layering structures, but use the structures as an additional tracer to infer the movement of the water masses. In Sect. 4 we examine different hypotheses about the formation areas, and the spreading, of the layerings 

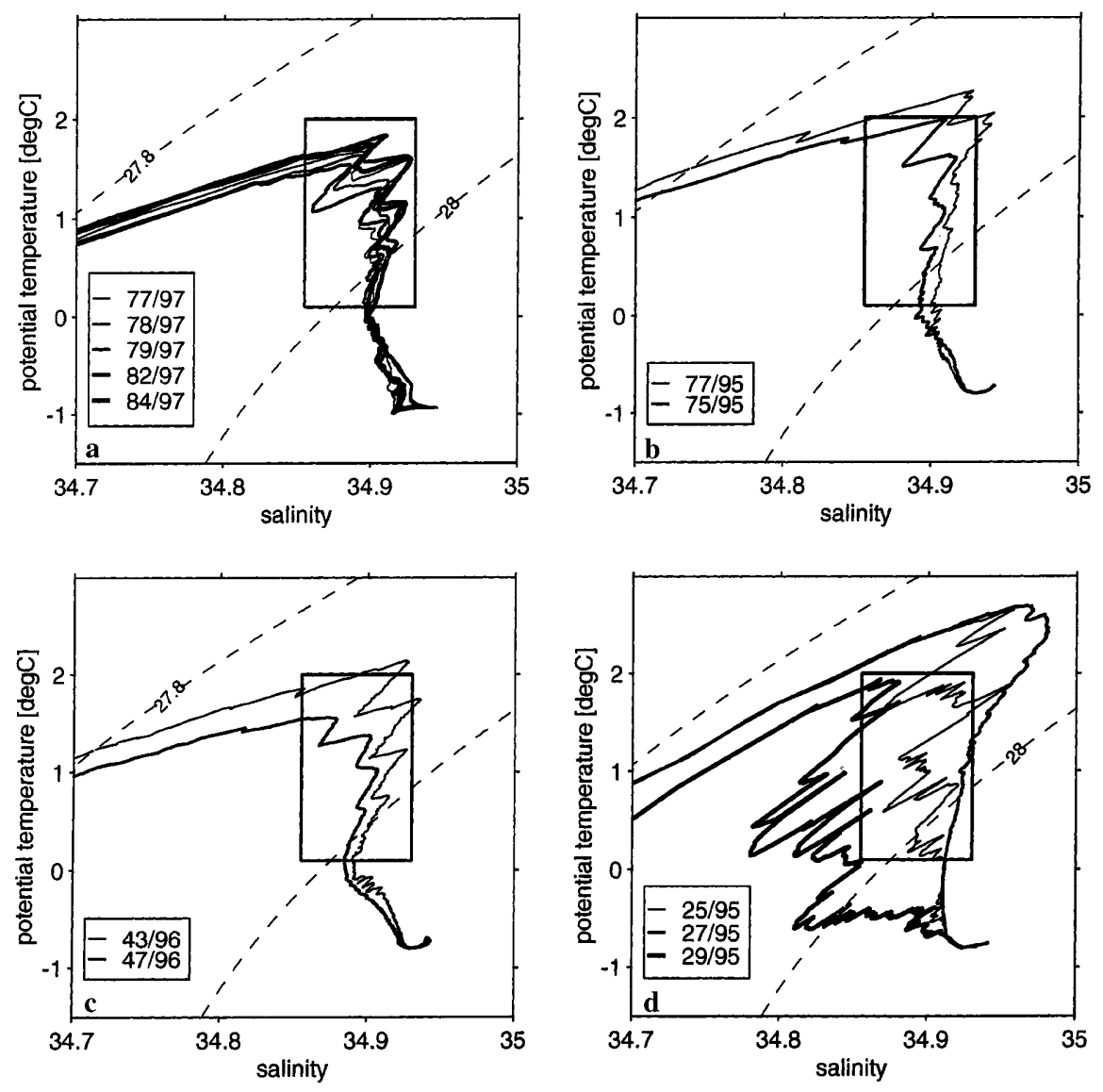

Fig. 9a-d. $\Theta-S$ diagrams showing the interleaving structures observed on a section III, and $\mathbf{b}$ in the interior of northern Nansen Basin and over the Nansen Gakkel Ridge in 1995, and $\mathbf{c}$ in 1996, and $\mathbf{d}$ the interleaving between the Fram Strait and the Barents Sea branches north of Severnaya Zemlya in 1995. The boxes are inserted to better show the $\Theta-S$ range of the interleaving

in the Arctic Ocean, to deduce the circulation paths of the AW, especially in the Eurasian Basin.

Sharp, more irregular interleaving structures were observed on sections I and IV (Fig. 10a, b). However, here individual layers could not be followed between neighbour stations in spite of the close station spacing. The high temperatures on section I (Fig. 10a) indicated that the layers were formed by local interactions between the southward flowing MAW and the recirculating AW of the West Spitsbergen Current (RAC) (Bourke et al., 1988), joining the East Greenland Current. On section IV (Fig. 10b) the interactions would be between the AW of the fragmented and partly recirculating West Spitsbergen Current and MAW deflected eastward (Fig. 5).

The temperature and the salinity of the AW in the western inflow branch decreased from section IV to sections II and III, indicating mixing with colder waters. However, no prominent intrusions were present, and none could be followed around the Yermak Plateau (Fig. 10c).

Irregular inversions were observed further to the west on section II (Fig. 10d). No RAC was present, and the lower temperatures suggested that the main mixing must be between MAW exiting from the Canadian Basin and the Eurasian Basin respectively. Since these waters have their first encounter close to the Morris Jesup Plateau, these inversions are also likely to be created locally in northern Fram Strait.

\section{Layering and circulation in the Eurasian Basin}

Perkin and Lewis (1984) explained the inversions they observed north and east of the Yermak Plateau by isopycnal, intrusive mixing at the front between Atlantic Water (AW) entering through Fram Strait and "old" Atlantic Water of the Arctic Ocean (MAW). These ideas have recently been elaborated by Carmack et al. (1997) and Swift et al. (1997), who proposed that the main ventilation of the Atlantic Layer in the Nansen Basin occurs by double-diffusively driven advection in interleaving layers, spreading from the boundary current into the interior of the basin.

If this were the case, and if a change in characteristics of the inflowing AW occurs, the change should first be observed in the layering structures north of the Yermak Plateau, closest to the inflow. The anomalously warm AW pulse in the Arctic Ocean in the 1990s was first seen in the boundary current north of the Kara Sea in 1990 (Quadfasel et al., 1991). No correspondingly high temperatures were, however, observed in the layering north of the Yermak Plateau in 1991 (see Fig. 5 in Rudels et al., 1994). Layerings, warmer but otherwise similar to those observed at the Yermak Plateau in 1997, were found in the eastern part of the Nansen Basin and the Nansen-Gakkel Ridge in 1995 (Fig. 9b) and in the central part in 1996 (Fig. 9c). This would imply a uniform, and simultaneous spreading of the layers from the boundary current into the Eurasian Basin water 

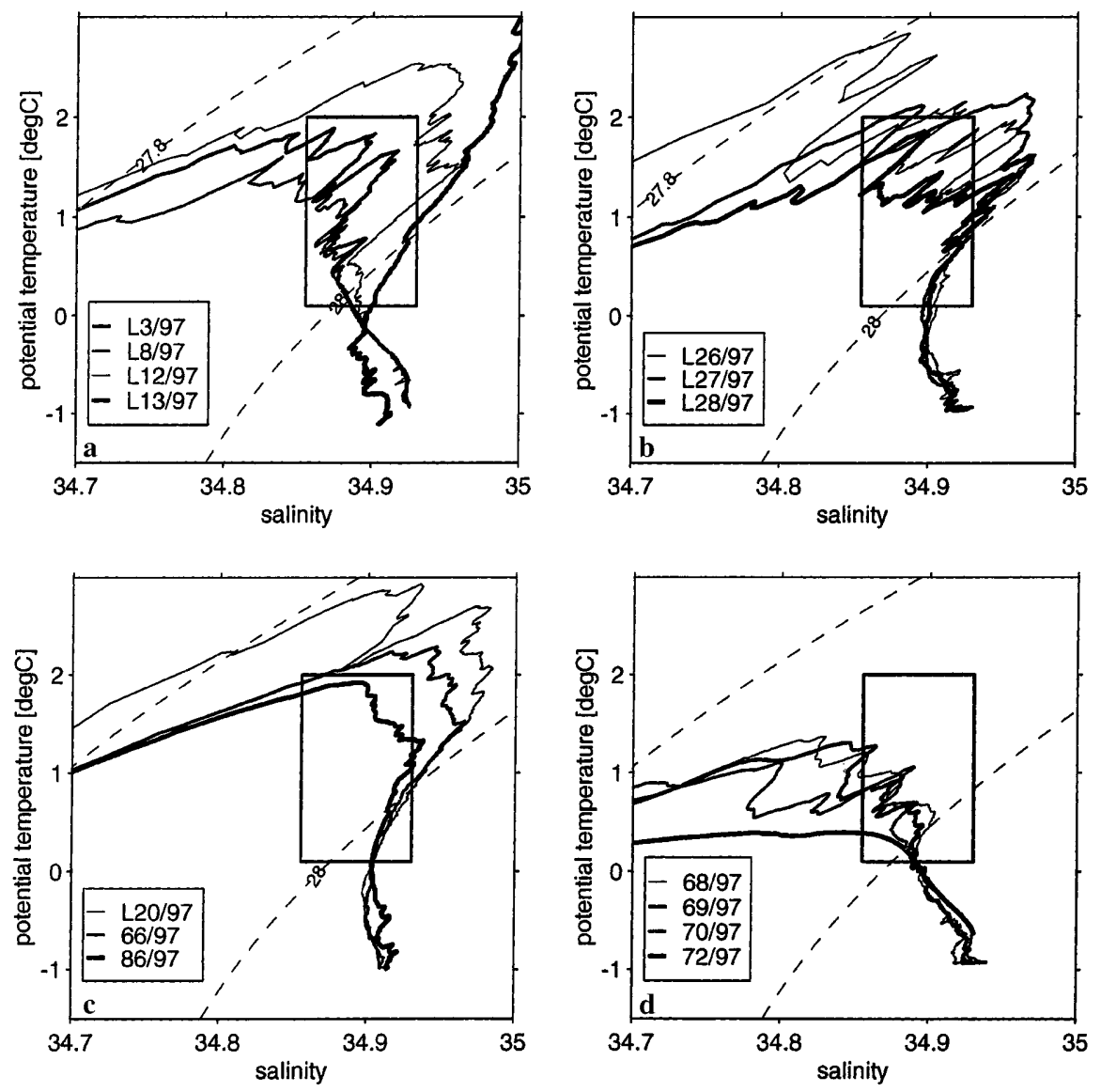

Fig. 10a-d. $\Theta-S$ diagrams showing the interleaving structures observed a on section I at the Greenland slope, and $\mathbf{b}$ on section IV west of the Yermak Plateau. $\mathbf{c}$ the evolution of the inflow around the Yermak Plateau, and $\mathbf{d}$ the interleaving observed on section II. The inserted boxes are the same as in Fig. 9 column along the entire Eurasian continental slope, reaching the Nansen Gakkel Ridge at about the same time. During the same period the core of the Fram Strait inflow branch did not exhibit any intrusions of colder basin water north of the Kara Sea and north of Severnaya Zemlya (Station $27 / 95$ in Fig. 9d). This is surprising since the layering should expand in both directions, and the width of the Fram Strait branch core is much smaller than the distance to the Nansen-Gakkel Ridge. By contrast, the Barents Sea branch, after it had entered the basin at the St. Anna Trough, interleaved rapidly with the AW core of the Fram Strait branch (Stations 25/95 and 29/95 in Fig. 9d).

If the layers penetrated from the boundary current to the Nansen-Gakkel Ridge in 2-3 years as suggested by (Swift et al., 1997), the interior along-basin advection of the Atlantic Layer must be slower than this. The layerings shown in Fig. 9a-c, although observed in different years, then belong to the same structure and are connected along the basin. Theoretical work (e.g., Toole and Georgi, 1991; McDougall, 1985a, b) has shown that Coriolis acceleration of the cross-front flow is balanced by an along-front slope of the layers, making the flow two-dimensional. The layers should then be located at different depths, or the uppermost layer should disappear and a new one form at the bottom of the interleaving structure, as we move along the front (see e.g., Garrett, 1982, Fig. 1). The vertical density gradient in the Atlantic Layer is $\sim 0.35 \times 10^{-3} \mathrm{kgm}^{-4}$, and with a layer thickness of $100 \mathrm{~m}$ (Fig. 11), an advection velocity in the layers of $0.005 \mathrm{~ms}^{-1}$ (Carmack et al., 1997; Swift et al., 1997), and with the Coriolis parameter $f=1.4 \times 10^{-4} \mathrm{~s}^{-1}$ the along-front slope of the isopycnals becomes 0.002 . Since the flow in the layering changes direction between the layers, the density of the layers must change also along the front, and their slope must thus be larger, roughly by a factor of 2 , than that of the isopycnals. The distance between the 1995 and the 1997 observations is $\sim 1500 \mathrm{~km}$, which implies that a layer makes a vertical excursion of $6000 \mathrm{~m}$, or that at a given level 20 different layers are encountered, as we move along the basin. The observational coverage to determine such appearance and disappearance of layers does not exist, but from the observations we do have, it is clear that layers from different parts of the Eurasian Basin that line up in the $\Theta-S$ diagrams, also are located roughly at the same depth (Fig. 11). A rapid, doublediffusively driven, penetration of the layering from the slope into the basin thus seems doubtful.

Rudels et al. (1994) concluded that the layering is formed in the boundary current north of the Kara Sea by interactions between the Barents Sea and the Fram Strait inflow branches. The expansion of the layers only occurs in a limited area close to the front, where, and as long as, the stability ratios are small, After this the double-diffusively driven motions all but cease. The slowly evolving layering structures are then advected with the boundary current, and enter the interior of the 


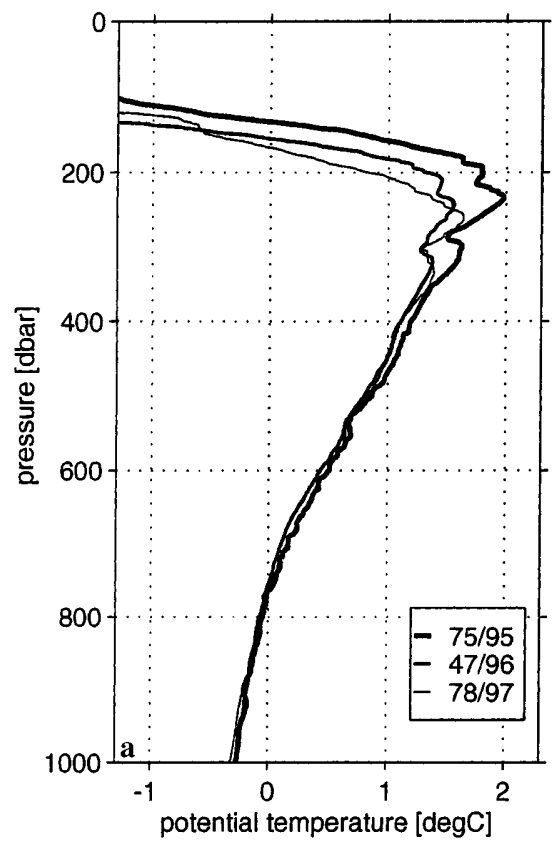

Fig. 11. a Temperature profiles and b salinity profiles from stations $75 / 97,47 / 96$ and 78/97 along the Nansen-Gakkel Ridge showing the depths of the inversions
Eurasian Basin, where a part of the boundary current, now comprising the two inflow branches, leaves the continental slope. Such separation occurs north of the Laptev Sea, forming a return flow toward Fram Strait, primarily along the northern Nansen Basin and the Nansen-Gakkel Ridge. The Fram Strait branch water dominates in the central Nansen Basin, making the layering warmer and more saline there than over the Nansen-Gakkel Ridge, where more Barents Sea branch water is found (Fig. 9b, c). The temperatures and salinities of the layers observed north and west of the Yermak Plateau fall within the range of those in the eastern Nansen Basin (Fig. 9). A salinity minimum originating from the Barents Sea inflow (see Sect. 5) was evident below the Atlantic Layer in the interior of the Eurasian Basin, as well as on the stations northwest of the Yermak Plateau (Fig. 9).

The presence of layering structures away from the frontal zones is then due to advection with the mean flow, and not the result of a self-propagation driven by double-diffusive convection. Assuming that the same water mass was encountered in the interior of the Eurasian Basin in 1995, and in 1996, and north of the Yermak Plateau in 1997, an along-basin advection velocity of about $2 \mathrm{cms}^{-1}$ can be estimated. However, the layering structures could have formed any time between 1991 and 1997, putting a lower limit on the velocity of $0.5 \mathrm{cms}^{-1}$.

The interleavings observed in Fram Strait proper were all different, in spite of the short distances between the sections, and it was not possible to follow individual layers from station to station. This has to be compared to the close similarity between the layerings found over large distances in the Eurasian Basin (Figs. 9, 10). It implies that interleaving occurs at almost all frontal zones, but the expansion of the interleaving layers is limited to the area close to their formation, and their extension depends on the conditions after their formation. If they are created between two water bodies moving in the same direction, e.g., as in the confluence of the Fram Strait and the Barents Sea branches in the boundary current east of St. Anna Trough, they have a chance to evolve and spread. Because parts of the boundary current separate from the continental slope at different locations, and advect into the low-energy environment of the deep basins, a widespread presence of the interleaving structures in the interior of the Arctic Ocean results, which, in the Eurasian Basin, can be traced from the eastern Nansen Basin to north of Fram Strait.

\section{The Intermediate Waters, uPDW and AIW}

Beneath the Atlantic Layer, the intermediate water masses of the Arctic Ocean and the Nordic Seas have similar $\Theta-S$ properties, but their $\Theta-S$ curves frequently have opposing slopes (Fig. 2). The Arctic Ocean intermediate waters are almost invariably stably stratified in both temperature and salinity, while the Nordic Seas waters often have an unstable distribution in one of the components.

The lower and upper Arctic Intermediate Waters (IAIW and uAIW), introduced by Swift and Aagaard (1981), are formed in the Nordic Seas, but by different mechanisms. The 1AIW consists mainly of cooled Atlantic Water of the West Spitsbergen Current that either enters the Arctic Ocean, or recirculates in Fram Strait. The UAIW is formed by winter convection in the Iceland and Greenland Sea, where cooling, and perhaps also freezing and brine rejection, allow less saline surface water to be mixed into the underlying Atlantic Water. The uAIW created in the Greenland Sea is denser than the IAIW, and when the uAIW spreads across the Mohns Ridge into the Norwegian Sea it forms a salinity minimum below the Atlantic Water (Blindheim, 1990). 
In our classification (Fig. 2) the densest part of the AW class corresponds to the 1AIW, while our AIW class comprises the intermediate water (uAIW) formed in the Greenland Sea.

In the Arctic Ocean the intermediate waters below the Atlantic Layer, but above the sill depth of the Lomonosov Ridge $(1700 \mathrm{~m})$, are denoted upper Polar Deep Water (uPDW) (Rudels et al., 1999). Its properties vary between the different basins. In the Canadian Basin the uPDW is characterized by increasing salinity and decreasing temperature with depth. Its upper part is less saline and colder than the water column in the Eurasian Basin but its deeper part is more saline and warmer. The uPDW of the Canadian Basin thus has a "flatter" slope in a $\Theta-S$ diagram than that of the Eurasian Basin. In the Eurasian Basin, the uPDW is separated from the Atlantic Layer by a salinity minimum, which is identified as originating from the Barents Sea branch entering in the St. Anna Trough (Rudels et al., 1994; Schauer et al., 1997, see also Fig. 9). In the Eurasian Basin, the uPDW is the lower part of a salinity minimum caused by an intruding, colder and less saline water mass, the Barents Sea branch. In the Canadian Basin it is the result of shelf-slope convection which redistributes heat and salt towards deeper levels.

On sections I and II uPDW was observed at the Greenland slope (Fig. 10a, d), but on most of the stations it is difficult to distinguish between the two sources, the Canadian Basin and the Eurasian Basin. Only station 72/97 (Fig. 10d) appears to have almost undiluted Canadian Basin uPDW. On section I, in the deep part of the strait east of the Greenland slope, colder and less saline intrusions were present (Station L13/97 in Fig. 10a). These originate from the colder AIW from the Greenland Sea, which interacts with the denser part of the UPDW, and the Canadian Basin Deep Water (CBDW) from the north.

Further north AIW was not observed on the western side of section II, and thus did not appear to penetrate much beyond $79^{\circ} \mathrm{N}$ in the western part of Fram Strait. It could, however, be followed from the southernmost station on section IV, across the central part of section I, to the northern part of section IV (Figs. 12a, 13). It was identified as a salinity minimum at the western and northern slopes of the Yermak Plateau and could be followed around the plateau into the Sofia Deep (Figs. 12b, 13). Its presence there was fairly weak, indicating extensive mixing with ambient water. The salinity minimum of the AIW is distinguished from the minimum associated with the Barents Sea branch by being slightly colder and somewhat more saline (compare Figs. 9, 10a, 10c, 12).

\section{The Deep Exchanges, CBDW, EBDW and NDW}

On section I, running along the sill in Fram Strait, the temperature and salinity decrease towards the bottom indicating a bottom layer deriving from the deep waters of the Nordic Seas (NDW) (Fig. 3a). North of the sill the warmer, more saline Arctic Ocean deep waters dominated and NDW was only found at the slope of the Yermak Plateau (Fig. 6). It could be followed along the western and northern slope of the plateau, where it mixed isopycnally with the Eurasian Basin Deep Water (EBDW) (Fig. 14). NDW was identified at the northeast corner of the Yermak Plateau in 1991 (Jones et al., 1995). In 1997 it was followed into the Sofia Deep (Figs. 12b, 15). At station 12/93, taken east of the Sofia Deep in 1993, the salinity in the intermediate and deep waters was also lower than what is observed elsewhere in the Eurasian Basin (Fig. 12b). Nevertheless, the influence from the Nordic Seas in the deeper layers of the
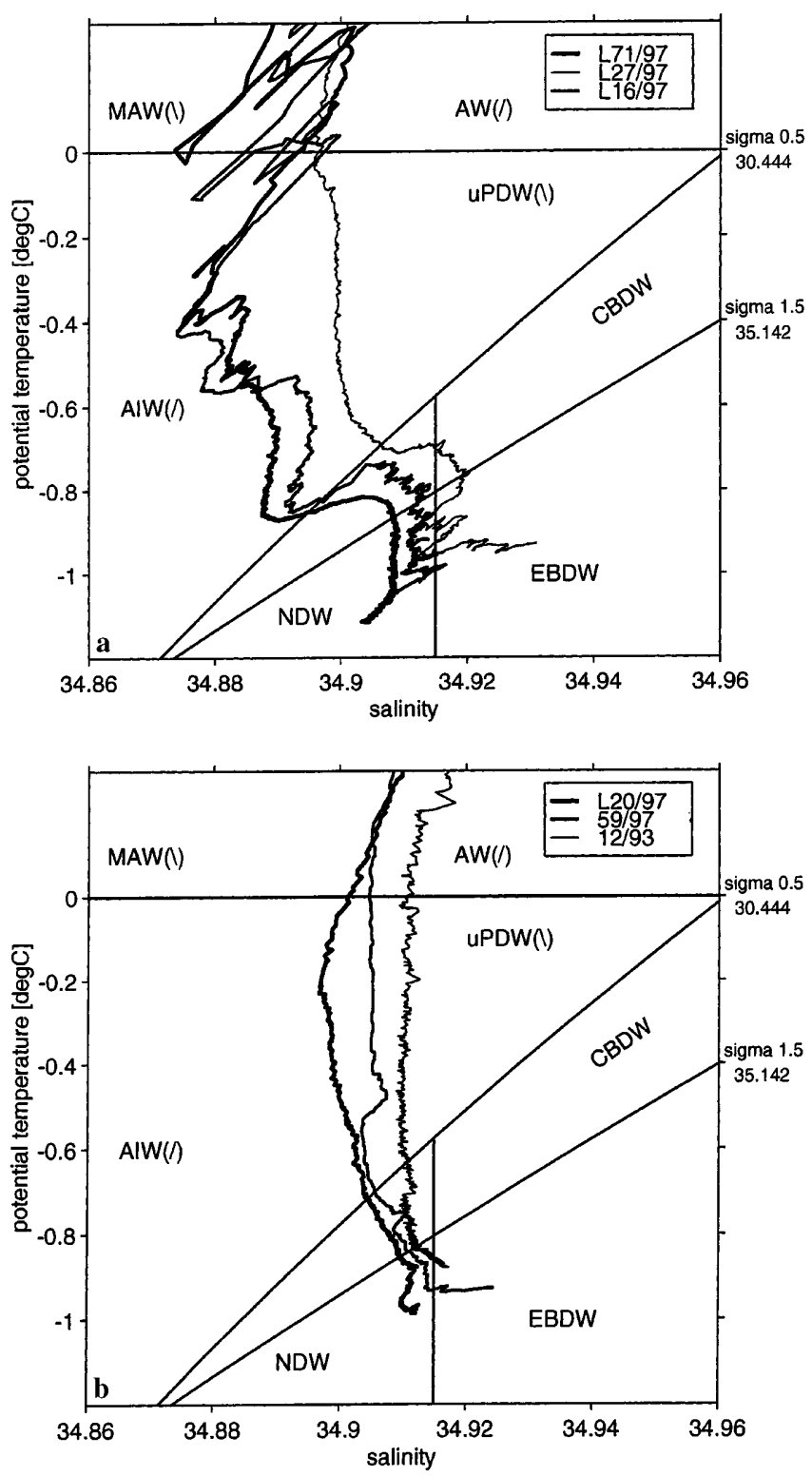

Fig. 12. a $\Theta-S$ diagram showing the salinity minimum of the Arctic Intermediate Water from the Greenland Sea as it penetrates northward from the southern part of section IV (L71/97), across section I (L16/97), and across the northern part of section IV ( $L 27 /$ 97). b $\Theta-S$ diagram indicating the penetration of $A I W$ and $N D W$ characterized by a salinity minima and also temperature minima $(N D W)$ around the Yermak Plateau and into the Sofia Deep (L20/97; $59 / 97$ and $12 / 93$ ) 


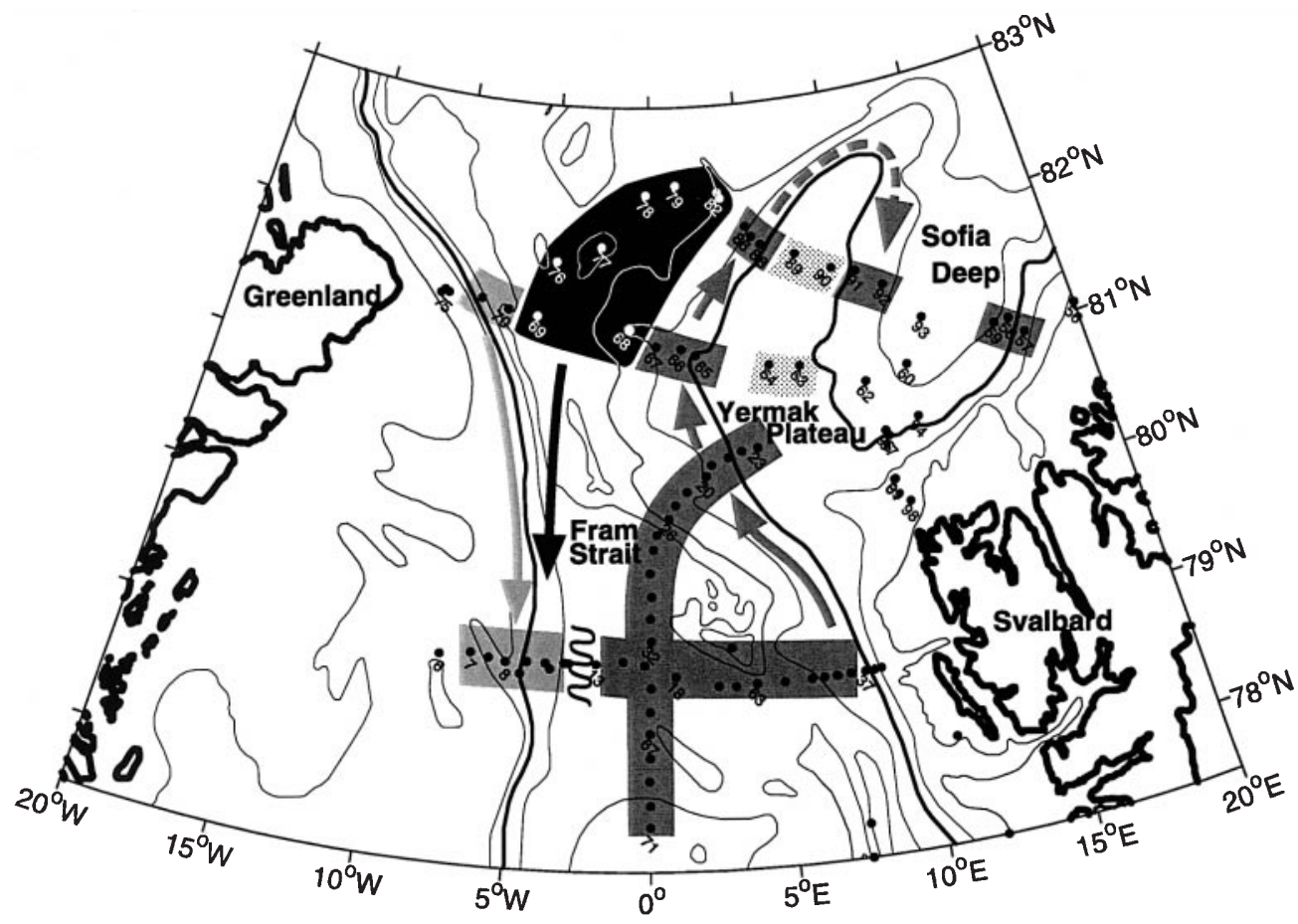

Fig. 13. Horizontal distribution of intermediate water masses. Dark gray areas show the presence of Arctic Intermediate Water (AIW), light gray denotes upper Polar Deep Water (uPDW) from the Canadian Basin and black shows the uPDW from the Eurasian Basin. The stippled area shows locally modified Atlantic Water. Arrows denote proposed pathways of the different waters. The wriggly line indicates interleaving between converging water masses

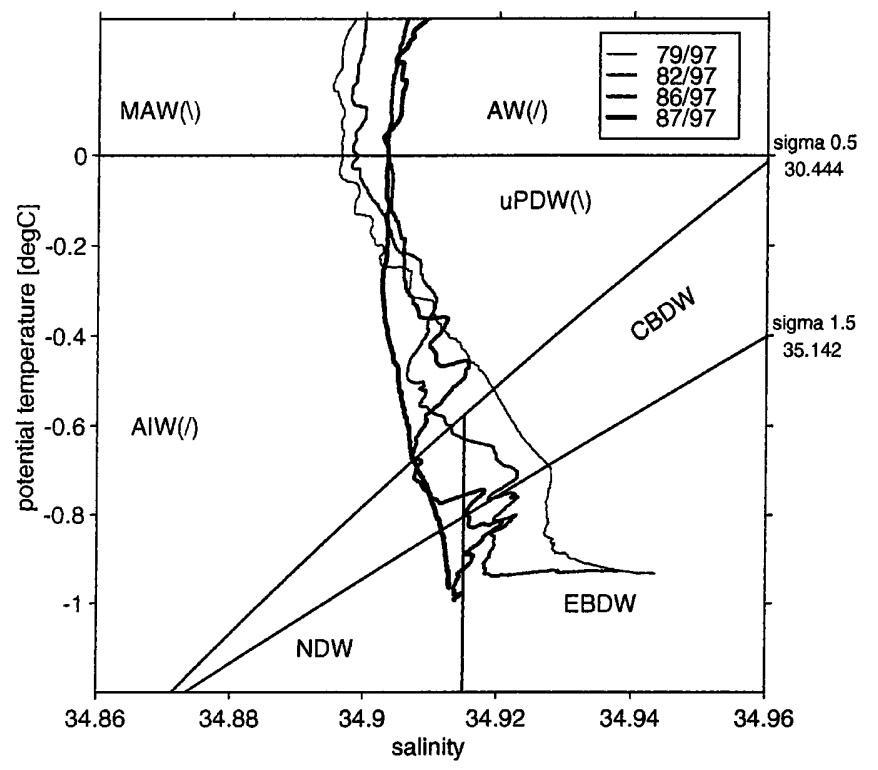

Fig. 14. $\Theta-S$ diagram showing the interleaving and mixing of the NDW with the Arctic Ocean deep waters north of the Yermak Plateau

Arctic Ocean disappears quickly, showing that NDW cannot be a major contributor to the Arctic Ocean deep waters.

Canadian Basin Deep Water (CBDW) that has crossed the Lomonosov Ridge into the Amundsen Basin shows up as an intermediate salinity maximum on the $\Theta-S$ curves (e.g. Figs. 10a, 12a), and can be followed along the northern Greenland slope into Fram Strait (Fig. 15). At depths between $2000 \mathrm{~m}$ and $2500 \mathrm{~m}$ the Eurasian Basin water column is colder and less saline than the CBDW, but below $2500 \mathrm{~m}$ its salinity increases steadily towards the bottom, and it forms a second, deep (bottom) salinity maximum north of the sill (Figs. 9, 11, 12 and 14). This maximum was strongest in the west but present over most part of the sill, where it was located above the colder, less saline NDW bottom layer (section I, Fig. 3a). The two salinity maxima associated with the CBDW and EBDW extend along the continental slope into the Greenland Sea and the upper, CBDW-derived maximum continues into the Iceland Sea (Aagaard et al., 1985, 1991; Buch et al., 1996; Rudels et al., 1999).

\section{Changes in the 1990s}

The observations in Fram Strait and at the Yermak Plateau in 1997 complement the many surveys in recent years, showing variations in the water masses exchanged between the Nordic Seas and the Arctic Ocean. By searching for evidence of the previously reported, anomalously warm AW in the Arctic Ocean, and in Fram Strait, we may deduce some features of the circulation of the Atlantic Water within the Arctic.

The high temperature of the MAW north of the Yermak Plateau, and the close correspondence between the layering structures observed in the interior in 1995 and 1996 and north-west of the Yermak Plateau in 1997, suggest that one circulation loop is confined to the Nansen Basin and carries mainly Fram Strait branch water back to the strait in less than 10 years. A return stream from the Amundsen Basin to the northern Fram Strait was also proposed, based upon stations taken in 1991 (Rudels et al., 1994, Fig. 5). Such a clear connection cannot be made using observations from 1996 and 1997. The temperatures in the central part of Fram 


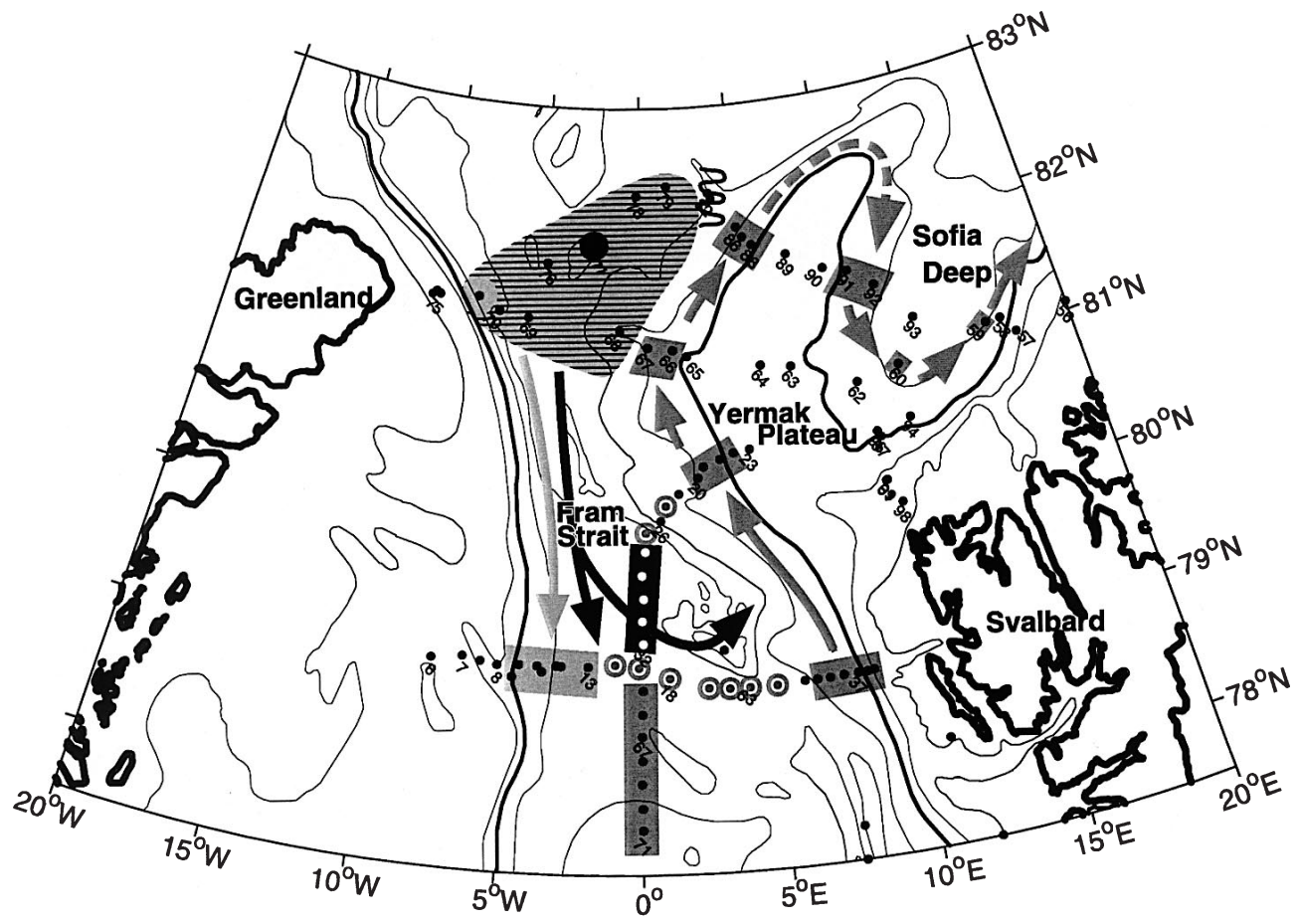

Fig. 15. Horizontal distribution of deep water masses. Dark gray shading shows the presence of NSD. Light gray denotes EBDW and black (as well as black hatching) shows overlying CBDW. Arrows denote proposed pathways of the different waters. Circles show stations with mixed deep water masses. The wriggly line indicates interleaving between converging water masses
Strait were higher than those found on the Oden stations but lower than those observed in the Amundsen Basin in 1996 (e.g., compare Fig. 10d with Fig. 3 in Rudels et al., 1999). The intermediate temperatures of the Amundsen Basin MAW in the strait could be due to local mixing between the different streams, especially with warmer MAW returning along the Nansen-Gakkel Ridge, and give no certain indication that the temperature increase observed at the Lomonosov Ridge between 1991 and 1994 (Swift et al., 1997) now has reached Fram Strait. The return flows in the Amundsen Basin, and along the Lomonosov Ridge, would then be less rapid than in the Nansen Basin. The low temperatures of the Canadian Basin MAW found at the Greenland continental slope also show that the pulse of warmer AW has not yet made a complete circuit in the boundary current around the entire Arctic Ocean (Fig. 10d).

The deep winter homogenized PSW found north of the Yermak Plateau and in western Fram Strait in 1997 differed from the PSW observed between the Morris Jesup Plateau and the Yermak Plateau in 1991, which had a more "classical" shape, i.e., a low salinity PML overlying a distinct halocline (Station 47/91 in Fig. 8a). In 1997 the winter homogenized part was more akin to the deep mixed layers reported from the Amundsen Basin in 1995 (Steele and Boyd, 1998) and also observed in the eastern Nansen Basin in 1996 (Station 50/96 in Fig. 8a). Not having any observations between the interior of the Eurasian Basin and Fram Strait we cannot determine, if in 1997, the area with a saline, deep upper layer extended from the central Eurasian Basin into Fram Strait, or if only a smaller patch was advected from the Eurasian Basin to the strait. The low salinity surface water observed at the Greenland slope far to the west, by contrast, implies a large input of PSW originating from the Canadian Basin.
The distribution of potential temperature and salinity on section I was different from that on corresponding sections occupied in the $1980 \mathrm{~s}$ as can be seen by comparing Fig. 3a and Fig. 16, which shows a Lance section along $78^{\circ} 55^{\prime} \mathrm{N}$ taken in 1984 . The cross-sectional area of water colder than $-1{ }^{\circ} \mathrm{C}$ is reduced, and the deep layers have become warmer, more saline and more dominated by Arctic Ocean deep waters in 1997. The westward extension of the recirculating AW was also smaller in 1997. In the 1980s, it almost always reached the Greenland slope at $79^{\circ} \mathrm{N}$, as well as at $80^{\circ} \mathrm{N}$ (Rudels et al., 1999, Fig. 2), and MAW exiting from the Arctic Ocean was only found close to the Greenland slope. Often MAW was not distinguished at all in the $\Theta-S$ curves, being absorbed by the RAC (Fig. 17). In 1984 the AW of the RAC was more saline and extended to higher density levels, and the salinity minimum formed below the RAC was colder $\left(-0.2<\Theta<0.2{ }^{\circ} \mathrm{C}\right)$ in 1984 than in $1997\left(\Theta \sim 0.2{ }^{\circ} \mathrm{C}\right)$. The stronger recirculation of AW also appeared to raise, by isopycnal mixing, the temperature and salinity of the outflowing uPDW. The AIW had a larger temperature and density range in 1997, its upper part being warmer and less dense than in 1984. Finally the deep waters were colder, less saline and denser in 1984 (Fig. 17).

\section{Conclusions}

1. The outflowing PSW displayed two distinct modes. A saline mode in the central part of the strait that lacked an upper, low salinity, PML and could be traced back to the deep winter mixed layer previously observed in the interior Eurasian Basin. The second mode was found close to Greenland. The PML here had low salinity and was located above a well- 
developed halocline, indicating PSW from the Canadian Basin.

When the mixed layer extends from the sea surface to the thermocline, there is no halocline in which heat transported upward from the Atlantic Layer may be trapped. It has been argued that the oceanic heat flux then could affect the thickness and extent of the ice cover (Steele and Boyd, 1998). However, apart from the seasonal heating at the surface, the temperature of the
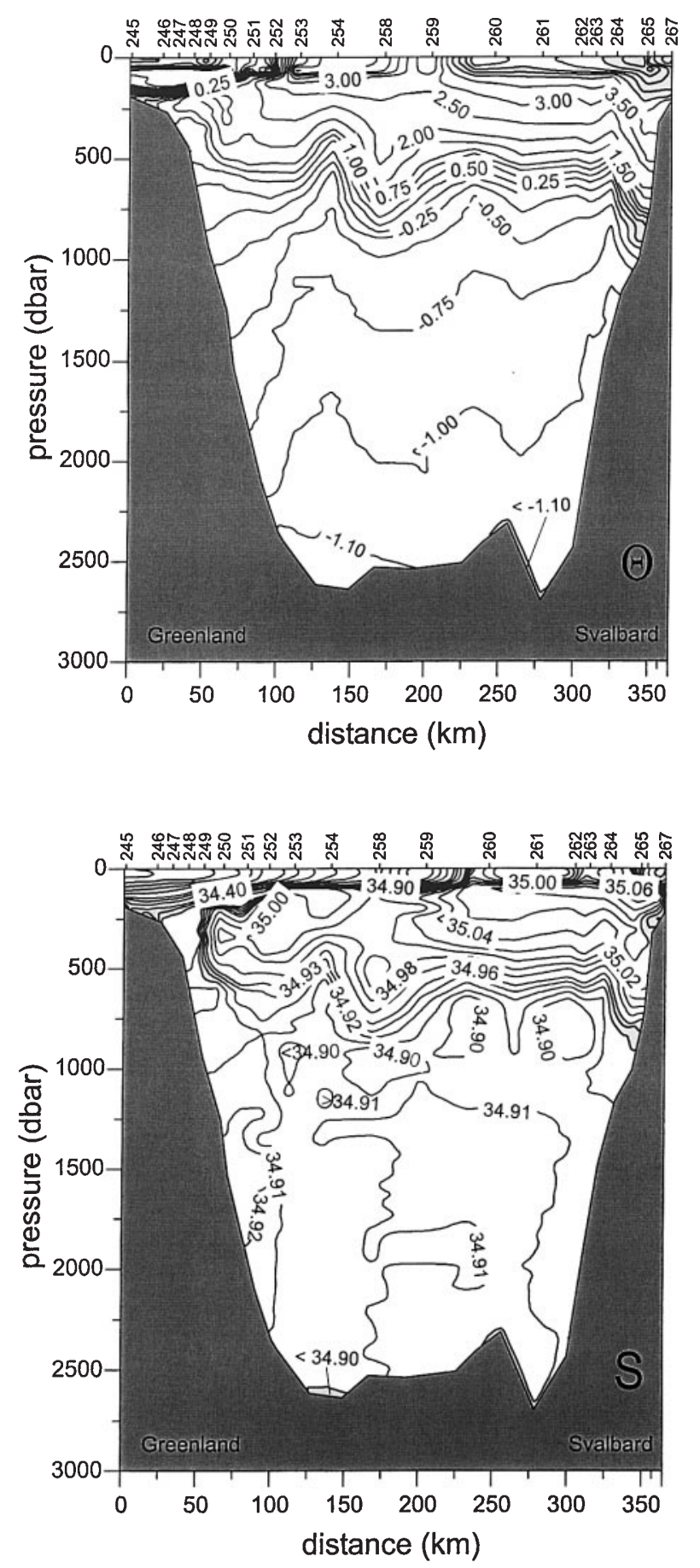

Fig. 16. The distribution of potential temperature and salinity on a section taken across Fram Strait along $78^{\circ} 55^{\prime} \mathrm{N}$ by RV Lance in late August 1984
PSW is close to freezing down to the thermocline, showing that the lower part of the mixed layer is homogenized by haline convection. Heat is only transferred from the Atlantic Layer to the sea surface in winter, and the strength of this transfer depends upon the ice production. Should input of heat from below reduce the ice formation, the convection would weaken and the upward heat transport be reduced, again increasing the ice formation. The ice in the interior of the Arctic Ocean is thus protected, as long as the mixed layer is deep enough to inhibit the effects of mechanical stirring.

Convection is not an efficient stirrer, and the heat loss of the Atlantic Water may actually be confined to the warming of convecting parcels that sink through the upper layer and enter the thermocline. The return flow to the surface would then consist of cold PSW that is displaced upward to compensate the downward mass transport connected with the by-passing plumes. The absence of stratification in the PSW above the Atlantic Layer may then not be that crucial for the existence of the ice cover.

The higher salinities of the PSW in the Eurasian Basin have been explained by changes in the meteorological conditions, associated with the extension of the cyclone tracks from the North Atlantic into the Arctic, which could cause the run-off from $\mathrm{Ob}$, Yenisey and Lena to enter the East Siberian Sea and the Canadian Basin rather than the Eurasian Basin (Proshutinsky and Johnson, 1997; Steele and Boyd, 1998). Simultaneously the weakening of the atmospheric high-pressure cell over the Beaufort Sea forces the inflow from the Pacific Ocean closer to the North American continent. This may lead to a stronger outflow of low salinity PSW from the Canadian Basin, not just through the Canadian Arctic Archipelago, but also into the Eurasian Basin and ultimately through Fram Strait, explaining the low salinities of the surface water close to Greenland. The variation in the atmospheric circulation, which is believed responsible for the dislocation of much of the Eurasian river run-off to the Canadian Basin, then also collects the less-dense surface water directly north of the North American continent. This trend had already started between the late 1970s and the early 1990s (Anderson et al., 1994). Such density structure in the upper part of the Arctic Ocean allows the PSW from the Canadian Basin, comprising the low-salinity Pacific Water and much of the river run-off, to rapidly reach the outflow area in Fram Strait in a buoyant, geostrophically balanced boundary current (Griffiths and Linden, 1981) rather than by the slower transpolar drift.

2. The water mass distribution in 1997 showed no sign of westward recirculation of AW north of $80^{\circ} \mathrm{N}$, but indicated a distinct Atlantic inflow core north of the Yermak Plateau, in contrast to the interpretation by Bourke et al., (1988). This western core was, however, colder than the water found in the Sofia Deep, which supports the idea that AW in the Sofia Deep derives from the eastern inflow branch close to Svalbard (Aagaard et al., 1987; Bourke et al., 1988). The western inflow branch probably rejoins the boundary current 

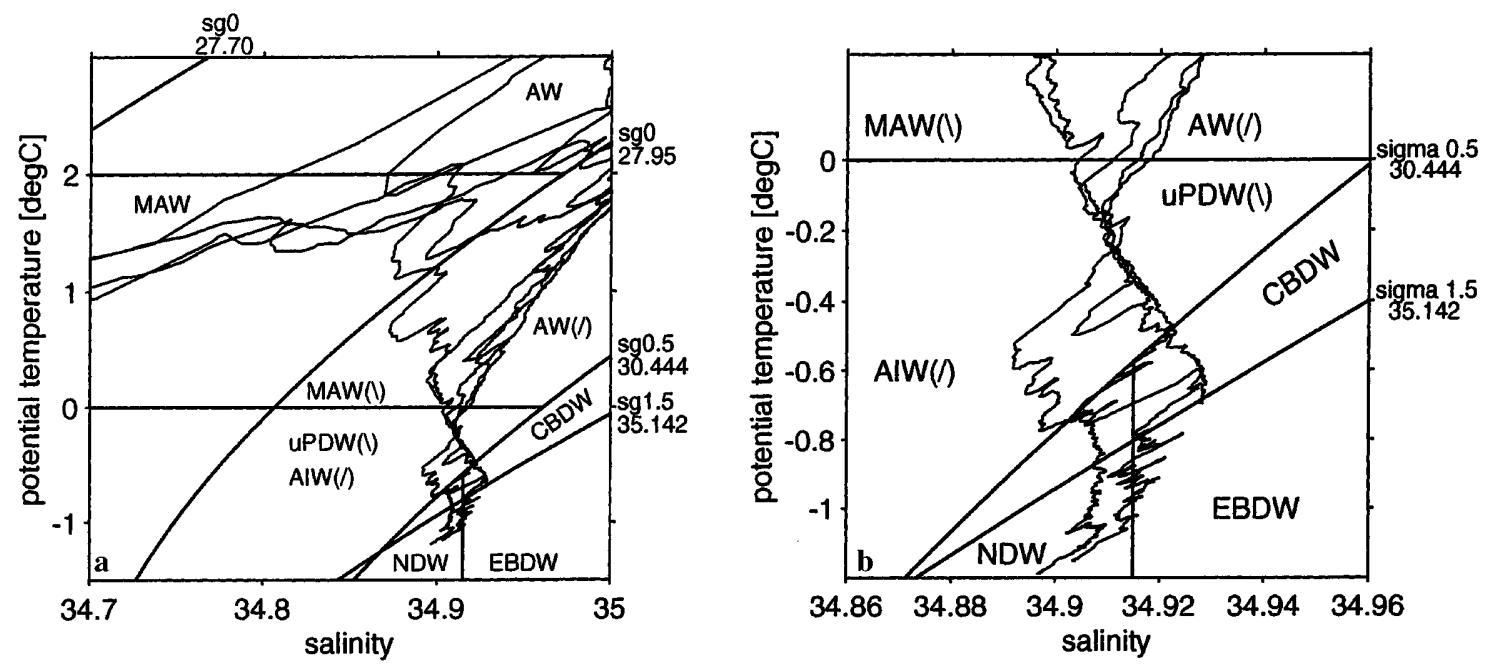

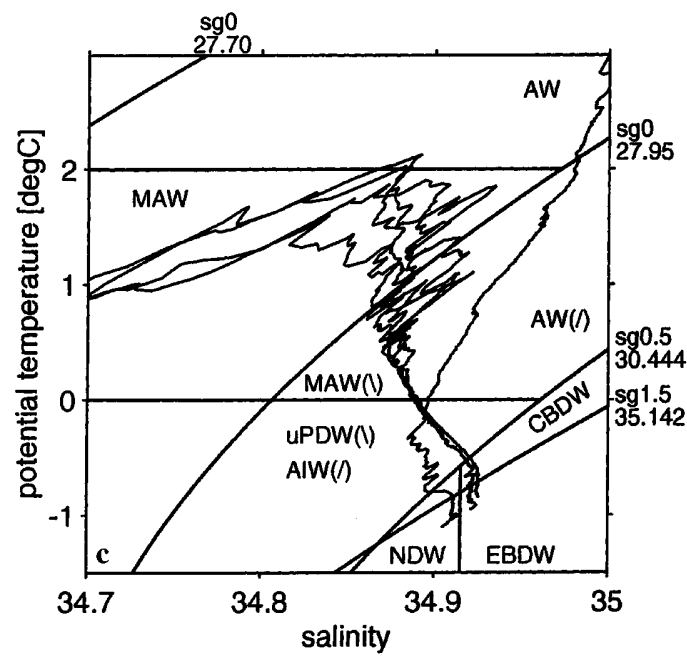

Fig. 17a-d. First row, $\Theta-\mathrm{S}$ diagrams for the 1984 Lance stations L249/84, L250/84, L251/84, L252/84 and L253/84, a full scale, b blow-

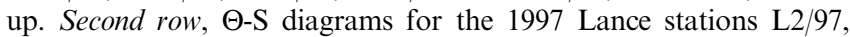

east of the plateau and continues eastward as suggested by Perkin and Lewis (1984). AIW and NDW were also identified north of the Yermak Plateau but strongly diluted by mixing with Arctic Ocean water masses. Their influence on the deeper layers of the Arctic Ocean is thus likely to be small. The 1997 observations appear to have missed the AW crossing the Yermak Plateau directly into the Sofia Deep as discovered by Gascard et al. (1995).

3. Except on section III the layering structures observed in Fram Strait displayed large variations over short distances. On section III the layers showed close resemblance, not just between stations on the section, but also to the layering structures recently observed in the eastern and central Eurasian Basin. This suggests a return flow in the northern Nansen Basin and over the Nansen-Gakkel Ridge toward Fram Strait more rapid than the recirculation along the Lomonosov Ridge, and that the northern Nansen Basin and the Nansen-Gakkel Ridge are ventilated by this return flow. The wide distribution of layerings in the Arctic Ocean implies that
L4/97, L8/97, L11/97 and L13/97, c full scale, d blow-up. The stations are located roughly at the same positions, and the figure shows the differences in water mass properties between the two years

layers created at frontal zones, may, if the mean circulation is favorable, spread over most part of the low-energy Arctic Ocean interior and only become disrupted, when other frontal zones are encountered.

4. In 1997 the AW of the West Spitsbergen Current only occupied about 3/4 of the width of Fram Strait and a free passage existed, not only for the Arctic Ocean deep waters but also for the MAW. The recirculation in the northern part of the strait thus appeared to be weaker than in the 1980s (Bourke et al., 1998; Quadfasel et al., 1987), implying that a larger part of the West Spitsbergen Current may enter the Arctic Ocean, taking the longer routes in the interior of the Arctic Ocean.

Are such variations caused by the local forcing in Fram Strait, or could changes in the recirculation in Fram Strait be related to other, recently observed, changes in the Arctic Mediterranean Sea, such as higher temperatures in the boundary current in the Arctic Ocean, and shallower convection and less deep and bottom water formation in the Greenland Sea? A conceivable, but speculative scenario could then be: in 
periods with formation of really dense water and convection into, and renewal of, the deep and bottom layers in the Greenland Sea, the density and volume of the deeper layers increase, and they eventually make up almost the entire water column. The doming of the isopycnals becomes stronger, favoring a more intense circulation around the Greenland Sea. This could cause the northward flowing AW of the West Spitsbergen Current to more readily recirculate in Fram Strait, supplying the RAC.

The convection in the Greenland Sea presently only ventilates the AIW above the intermediate temperature maximum (Budéus et al., 1998). The intermediate temperature maximum in the Greenland Sea, ultimately originating from CBDW leaving the Arctic Ocean (Meincke et al., 1997), has gradually been displaced to deeper levels (Budéus et al., 1998). At the same time the salinity at, and below, the temperature maximum has increased, indicating a continuous supply of CBDW, and EBDW, from the East Greenland Current and the continental slope to the interior of the Greenland Sea (See Plates 1-4, and Fig. 5 in Budéus et al., 1998). If the present situation prevails, the deep waters reaching Fram Strait from the south will be just slightly modified Arctic Ocean deep waters returning from the Greenland Sea.

When the density of the convecting water is less, the doming will be reduced and the circulation around the Greenland Sea weaker. More AW would then continue into the Arctic Ocean and follow the longer loops in the different basins. The formation of less dense water in the Greenland Sea would then be connected with stronger exchanges of AW and MAW through Fram Strait, and with a closer coupling between the Arctic Ocean and the Nordic Seas. Such scenario emphasises the effects of long-term, gradual changes in the thermohaline structure of the water columns in the Arctic Ocean and the Nordic Seas for the circulation in, and the exchanges through, Fram Strait.

Acknowledgement. The present work was supported by the European Commission MAST III Programme VEINS, through contract MAS3-CT96-0070, and by the German ACSYS programme, BMBF 03PL020E.

The Editor-in-chief thanks a referee for his help in evaluating this paper.

\section{References}

Aagaard, K., and E. C. Carmack, The role of sea ice and other fresh water in the Arctic circulation, J. Geophys. Res., 94, 14 48514 498, 1989.

Aagaard, K., and P. Greisman, Towards new mass and heat budgets for the Arctic Ocean, J. Geophys. Res., 80, 3821-3827, 1975.

Aagaard, K., C. Darnall, and P. Greisman, Year-long measurements in the Greenland-Spitsbergen passage, Deep-Sea Res., 20, 743-746, 1973.

Aagaard, K., L. K. Coachman, and E. C. Carmack, On the halocline of the Arctic Ocean, Deep-Sea Res., 28, 529-545, 1981.

Aagaard, K., J. H. Swift, and E. C. Carmack, Thermohaline circulation in the Arctic Mediterranean Seas, J. Geophys. Res., 90, 4833-4846, 1985.
Aagaard, K., A. Foldvik, and S. R. Hillman, The West Spitsbergen Current: disposition and water mass transformation, J. Geophys. Res., 92, 3778-3784, 1987.

Aagaard, K., E. Fahrbach, J. Meincke, and J. H. Swift, Saline outflow from the Arctic Ocean: its contribution to the deep waters of the Greenland, Norwegian and Icelandic seas, J. Geophys. Res., 96, 20 433-20 441, 1991.

Anderson, L. G., G. Björk, O. Holby, E. P. Jones, G. Kattner, K.-P. Koltermann, B. Liljeblad, R. Lindegren, B. Rudels, and J. H. Swift, Water masses and circulation in the Eurasian Basin: results from the Oden 91 Expedition. J. Geophys. Res., 99, 3273-3283, 1994.

Blindheim, J., Arctic Intermediate Water in the Norwegian Sea, Deep-Sea Res., 37, 1475-1489, 1990.

Bourke, R. H., A. M. Weigel, and R. G. Paquette, The westward turning branch of the West Spitsbergen Current, J. Geophys. Res., 93, 14 065-14 077, 1988.

Buch, E., S.-A. Malmberg, and S. S. Kristmannsson, Arctic Ocean deep water masses in the western Iceland Sea, J. Geophys. Res., 101, 11 965-11 973, 1996.

Budéus, G., W. Schneider, and G. Krause, Winter convective events and bottom water warming in the Greenland Sea, J. Geophys. Res., 103, 18 513-18 527, 1998.

Coachman, L. K., and K. Aagaard, Physical Oceanography of the Arctic and Sub-Arctic Seas in, Marine geology and oceanography of the Arctic Ocean, Ed. Y. Herman, Springer, New York, Berlin Heidelberg pp 1-72, 1974.

Carmack, E. C., Large-scale physical oceanography of Polar Oceans, in Polar oceanography, Part A, Ed. W. O. Smith, Jr., Academic Press, San Diego, California, 171-212, 1990.

Carmack, E. C., R. W. Macdonald, R. G. Perkin, F. A. McLaughlin, and R. J. Pearson, Evidence for warming of Atlantic Water in the southern Canadian Basin of the Arctic Ocean: results from the Larsen-93 expedition, Geophys. Res. Letts., 22, 1061-1064, 1995.

Carmack, E. C., K. Aagaard, J. H. Swift, R. W. Macdonald, F. M. McLaughlin, E. P. Jones, R. G. Perkin, J. N. Smith, K. M. Ellis, and L. R. Killius, Changes in temperature and tracer distributions within the Arctic Ocean: results from the 1994 Arctic Ocean section, Deep-Sea Res., II, 44, 1487-1502, 1997.

Foldvik, A., K. Aagaard, and T. Törresen, On the velocity field of the East Greenland Current, Deep-Sea Res., 35, 1335-1354, 1988.

Friedrich, H., M.-N. Houssais, D. Quadfasel, and B. Rudels, On Fram Strait Water Masses, Extended Abstract, Nordic Seas Symposium, Hamburg 7/3-9/3 1995, pp 69-72, 1995.

Garrett, C., On the parametrization of diapycnal fluxes due to double-diffusive intrusions. J. Phys. Oceanogr., 12, 952-959, 1982.

Gascard, J.-C., C. Richez, and C. Roaualt, New insights on LargeScale oceanography in Fram Strait: the West Spitsbergen Current, in Arctic oceanography, marginal ice zones and continental shelves, Eds. W. O. Smith, Jr. and J. M. Grebmeier, AGU 49, Washington DC 131-182, 1995.

Gorshkov, S. G., World Ocean Atlas 3, The Arctic Ocean, USSR Ministry of Defence, Leningrad, XIV, 180 pp, 1980.

Griffiths, R. W., and P. F. Linden. The stability of buoyancy-driven coastal currents. Dyn. Atmos. Oceans, 5, 281-306, 1981.

Helland-Hansen, B., and F. Nansen, The Norwegian Sea. Its physical oceanography based upon the Norwegian researches 1900-1904, Rep. on Norw. Fishery and Marine Investigations II(1), Kristiania, 1909.

Hunkins, K., Anomalous diurnal tidal currents on the Yermak Plateau, J. Mar. Res., 44, 51-69, 1986.

Jones, E. P., and L. G. Anderson, On the origin of the chemical properties of the Arctic Ocean halocline, J. Geophys. Res., 91, 10759-10767, 1986.

Jones, E. P., B. Rudels, and L. G. Anderson, Deep waters of the Arctic Ocean: origins and circulation, Deep-Sea Res., 42, 737$760,1995$. 
Jones, E. P., L. G. Anderson, and J. H. Swift, Distribution of Atlantic and Pacific Water in the upper Arctic Ocean: implications for the circulation. Geophys. Res. Letts., 25, 765-768, 1998.

Koltermann, K.-P., and H. Lüthje, Hydrographic Atlas of the Greenland and Northern Norwegian Seas (1979-1987). Deutsches Hydrographisches Institut, No. 2328, Hamburg, 274 pp, 1989.

May, B. D., and D. E. Kelley, Effect of baroclinicity on doublediffusive interleaving, J. Phy. Oceanogr., 27, 1997-2008, 1997.

McDougall, T. J., Double-diffusive interleaving Part I: linear stability analysis, J. Phys. Oceanogr., 15, 1532-1541, 1985b.

McDougall, T. J., Double-diffusive interleaving Part II: finite amplitude steady state interleaving, J. Phys. Oceanogr., 15, 1542-1556, 1985 b.

McLaughlin, F. A., E. C. Carmack, R. W. Macdonald, and J. K. B. Bishop, Physical and geochemical properties across the Atlantic/ Pacific water mass from in the southern Canadian Basin, J. Geophys. Res., 101, 1183-1197, 1996.

Meincke, J., B. Rudels, and H. J. Friedrich, The Arctic Ocean Nordic Seas thermohaline system, ICES J. Mar. Sci., 54, 283-299, 1997.

Morison, J., M. Steele, and R. Andersen, Hydrography of the upper Arctic Ocean measured from the nuclear submarine USS Pargo, Deep-Sea Res., 45, 15-38, 1998.

Mosby, H., Water, mass and heat balance of the North Polar Sea and of the Norwegian Sea, Geofys. Publ., 24(II), 289-313, 1962.

Muench, R. D., M. G. McPhee, C. A. Paulson, and J. H. Morison, Winter oceanographic conditions in the Fram Strait-Yermak Plateau region, J. Geophys. Res., 97, 3469-3483, 1992.

Nansen, F., Oceanography of the North Polar Basin, The Norwegian North Polar Expedition 1893-96. Scientific Results III (9), $427 \mathrm{pp}, 1902$.

Nansen, F., Northern waters. Captain Roald Amundsen's oceanographic observations in the Arctic seas in 1901, VidenskabsSelskapets Skrifter. I. Mathematisk-Naturv. Klasse 1906, (3), Dybwad, Christiania, 145 pp, 1906.

Nansen, F., Spitsbergen waters: oceanographic observations during the Cruise of the Veslemøy to Spitsbergen in 1912, Videnskabsselskabets skrifter I. Matematisk-Naturvidenskabelig Klasse 1915, (2), $132 \mathrm{pp}, 1915$.

Padman, L., and T. M. Dillon, Turbulent mixing near the Yermak Plateau during the Co-ordinated Eastern Arctic Experiment, J. Geophys. Res., 96, 4769-4782, 1991.

Padman, L., A. Plueddemann, R. D. Muench, and R. Pinkel, Diurnal tides near the Yermak Plateau, J. Geophys. Res., 97, 12 639-12 652, 1992.

Perkin, R. G., and E. L. Lewis, Mixing in the West Spitsbergen Current, J. Phys. Ocean., 14, 1315-1325, 1984.

Proshutinsky, A. Y., and M. A. Johnson, Two circulation regimes of the winddriven Arctic Ocean, J. Geophys. Res., 102, 12 49312 514, 1997.

Quadfasel, D., J.-C. Gascard, and K.-P. Koltermann, Large-scale oceanography in Fram Strait during the 1984 Marginal Ice Zone experiment, J. Geophys. Res., 92, 6719-6728, 1987.

Quadfasel, D., A. Sy, D. Wells, and A. Tunik, Warming in the Arctic, Nature, 350, 385, 1991.

Quadfasel, D., A. Sy, and B. Rudels, A ship of opportunity section to the North Pole: upper ocean temperature observations, DeepSea Res., 40, 777-789, 1993.

Ruddick, B., Intrusive mixing in a Mediterranean salt lens: intrusion slopes and dynamical mechanisms. J. Phys. Oceangr., 22, 1274-1285, 1992.
Ruddick, B., and J. S. Turner, The vertical scale of double-diffusive intrusions. Deep-Sea Res., 26, 903-913, 1979.

Rudels, B., The outflow of Polar Water through the Arctic Archipelago and the oceanographic conditions in Baffin Bay, Polar Res., 4 n.s., 161-180, 1986.

Rudels, B., On the mass balance of the Polar Ocean, with special emphasis on the Fram Strait, Nor. Polarinst. Skr., 188, 53 pp, 1987.

Rudels, B., E. P. Jones, L. G. Anderson, and G. Kattner, On the intermediate depth waters of the Arctic Ocean, in The role of the Polar Oceans in shaping the global climate, Eds. O. M. Johannessen, R. D. Muench, and J. E. Overland, American Geophysical Union, Washington, 33-46, 1994.

Rudels, B., L. G. Anderson, and E. P. Jones, Formation and evolution of the surface mixed layer and the halocline of the Arctic Ocean, J. Geophys. Res., 101, 8807-8821, 1996.

Rudels, B., G. Björk, R. D. Muench, and U. Schauer, Doublediffusive layering in the Eurasian Basin of the Arctic Ocean. J. Mar. Syst., 21, 3-27, 1999.

Schauer, U., R. D. Muench, B. Rudels, and L. Timokhov, Impact of eastern Arctic shelf water on the Nansen Basin intermediate layers, J. Geophys. Res., 102, 3371-3382, 1997.

Schauer, U., and S. Østerhus, Lance 6-97 Fram Strait (23 August to 17 September) Cruise Report, AWI, Ber. Fachbe. Phy., 82, $1-16,1997$.

Steele, M., and T. Boyd, Retreat of the cold halocline layer in the Arctic Ocean, J. Geophys. Res., 103, 10 419-10 435, 1998.

Steele, M., D. Thomas, D. Rothrock, and S. Martin, A simple model study of the Arctic Ocean freshwater balance 1979-198, J. Geophys. Res., 101, 20 833-20 848, 1996.

Steele, M., J. H. Morison, and T. B. Curtin, Halocline formation in the Barents Sea, J. Geophys. Res., 100, 881-894, 1995.

Stein, R., and K. Fahl, Scientific Cruise Report of the Arctic Expedition ARK-XIII/2 of RV 'Polarstern' in 1997, Ber. Polarforsc., 255, 235 pp, 1997.

Stern, M. E., Lateral mixing of water masses. Deep-Sea Res., 14, $747-753,1967$.

Swift, J. H., and K. Aagaard, Seasonal transitions and water mass formation in the Icelandic and Greenland Seas, Deep-Sea Res., 28, 1107-1129, 1981

Swift, J. H., E. P. Jones, E. C. Carmack, M. Hingston, R. W. Macdonald, F. A. McLaughlin, and R. G. Perkin, Waters of the Makarov and Canada Basins, Deep-Sea Res., II, 44, 1503-1529, 1997.

Timofeyev, V. T., The movement of Atlantic Water and heat into the Arctic sea basin, Okeanologiya, 1, 407-411, 1961.

Timofeyev, V. T., Interaction of waters from the Arctic Ocean with those from the Atlantic and the Pacific, Okeanologiya, 3, 569-578, 1963.

Toole, J. M., and D. T. Georgi, On the dynamics and effects of double-diffusively driven intrusions, Progr. Oceanogr., 10, 121-145, 1981.

Treshnikov, A. F., Ye. K. Nikiforov, and N. I. Blinov, Results of oceanological investigations by the North Pole drifting stations, Vopr. Geogr., 101, 49-69, 1976.

Untersteiner, N., On the ice and heat balance in Fram Strait, J. Geophys. Res., 92, 527-532, 1988.

Vowinckel, E., and S. Orvig, The climate of the North Polar Basin, in World Climate survey, vol 14: Climates of the polar regions, Ed. S Orvig, Elsevier, Amsterdam, 370 pp, 1970.

Wüst, G., Schichtung und Zirkulation des Atlantisches Ozeans. Das Bodenwasser und die Stratosphäre, Wiss. Erg. Deutsch. Atlant. Exp. Meteor 1925-27, 6, 1, Berlin, 180 pp, 1936. 